This item was submitted to Loughborough's Research Repository by the author.

Items in Figshare are protected by copyright, with all rights reserved, unless otherwise indicated.

\title{
Alternating a-olefin distributions via single and double insertions in chromium-catalyzed ethylene oligomerization
}

PLEASE CITE THE PUBLISHED VERSION

http://dx.doi.org/10.1021/acs.organomet.6b00671

PUBLISHER

ACS Publications (@ 2016 American Chemical Society)

VERSION

AM (Accepted Manuscript)

\section{PUBLISHER STATEMENT}

This work is made available according to the conditions of the Creative Commons Attribution-NonCommercialNoDerivatives 4.0 International (CC BY-NC-ND 4.0) licence. Full details of this licence are available at: https://creativecommons.org/licenses/by-nc-nd/4.0/

\section{LICENCE}

CC BY-NC-ND 4.0

\section{REPOSITORY RECORD}

Tomov, Atanas K., James D. Nobbs, Juan J. Chirinos, Prabhjot K. Saini, Robert Malinowski, Sarah K.Y. Ho, Craig T. Young, et al.. 2019. "Alternating A-olefin Distributions via Single and Double Insertions in Chromiumcatalyzed Ethylene Oligomerization”. figshare. https://hdl.handle.net/2134/23530. 


\title{
Alternating $\alpha$-Olefin Distributions via Single and Double Insertions in Chromium-catalysed Ethylene Oligomerisation
}

\author{
Atanas K. Tomov, ${ }^{a}$ James D. Nobbs, ${ }^{\text {a }}$ Juan J. Chirinos, ${ }^{a}$ Prabhjot K. Saini, ${ }^{a}$ Robert \\ Malinowski, ${ }^{a}$ Sarah K. Y. Ho, ${ }^{a}$ Craig T. Young, ${ }^{a}$ David S. McGuinness, ${ }^{\text {b }}$ Andrew J. P. \\ White, ${ }^{\mathrm{a}}$ Mark R. J. Elsegood ${ }^{\mathrm{c}}$ and George J. P. Britovsek ${ }^{\mathrm{a} *}$
}

a) Department of Chemistry, Imperial College London, Exhibition Road, London, SW7 2AZ, $U K$

b) School of Physical Sciences - Chemistry, University of Tasmania, Private Bag 75, Hobart 7001, Australia

c) Chemistry Department, Loughborough University, Loughborough, LE11 3TU, UK.

Keywords: ethylene, chromium, alpha-olefins, recurrence, alternation, 1-alkenes

\begin{abstract}
The catalytic oligomerisation of ethylene with chromium-based complexes containing bis(benzimidazolemethyl)amine (BIMA) ligands results in alternating distributions of linear $\alpha$-olefins (LAOs). Extremely high activities are obtained (>100,000 gmmol $^{-1} \mathrm{~h}^{-1} \mathrm{bar}^{-1}$ ) with $\mathrm{N}$-alkyl substituted BIMA ligands, whereas bulky groups on the central nitrogen or alternative central donors result in much lower activities. Variations in the ligand backbone, as well as methylation of the benzimidazole units lead to reduction in activity. The alternating LAO distributions have been mathematically analysed using second order recurrence relations. The shape of the distributions is affected by ethylene pressure (1-4 bar) and by the co-catalyst to some degree. Based upon the results and analysis presented herein, we propose that the alternating behaviour originates from the ability of these chromium BIMA catalysts to undergo single as well as double ethylene insertion reactions. A minor second distribution (<5 wt\%) of 2-ethyl-1-alkenes is obtained under certain conditions, resulting from incorporation of 1-butene. DFT studies (M06L) and experimental observations regarding the reaction between $\mathrm{AlMe}_{3}$ and the $\mathrm{N}$-methyl BIMA ligand 2 have shown that deprotonation of the benzimidazole N-H units can occur, which suggests a change in coordination of the BIMA ligand under oligomerisation conditions.
\end{abstract}




\section{Introduction}

Linear $\alpha$-olefins (LAOs) are important chemical intermediates for the production of detergents, lubricants and as co-monomers in linear low density polyethylene (LLDPE). ${ }^{1-4}$ Several commercial processes produce LAOs with different distributions of chain lengths. The Alfen process involves stepwise insertions of ethylene into the Al-C bonds of aluminium alkyls, resulting in a range of LAOs that follow a Poisson distribution. The Shell Higher Olefin Process (SHOP) oligomerises ethylene with a nickel-based catalyst (see Figure 1), ${ }^{5}$ where chain propagation competes with chain termination according to the Cossee mechanism, ${ }^{6}$ resulting in LAOs with a Schulz-Flory distribution. ${ }^{7,8}$ Several chromium complexes have been reported that oligomerise ethylene with high selectivity to 1-hexene or 1-octene, for example those based on PNP ligands, ${ }^{9-12}$ and more recently with $\mathrm{PNC}=\mathrm{N}$ and $\mathrm{PC}=\mathrm{N}$ ligand systems. ${ }^{13,14}$ The trimerisation of ethylene to 1-hexene with a pyrrole/chromium-based catalyst is operated by the Phillips Petroleum Company, ${ }^{15}$ and Sasol has recently commercialised a tri/tetramerisation technology based on PNP/chromium catalysts for the production of 1-hexene and 1-octene. ${ }^{16}$ Some examples of commercial oligomerisation catalysts are collected in Figure 1. Deuterium labelling studies have shown that many chromium catalysts operate via a metallacyclic mechanism rather than a Cossee chain growth mechanism. ${ }^{17-19}$

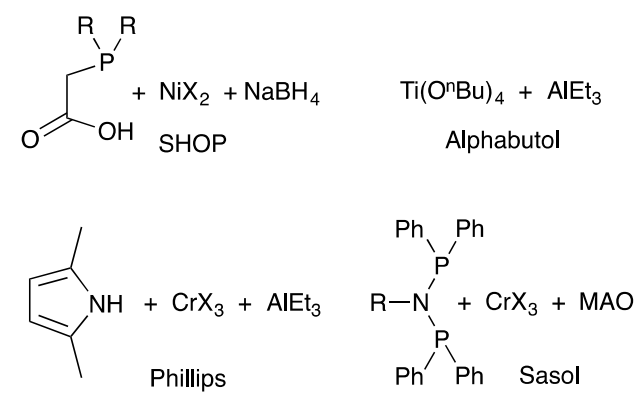

Figure 1. Examples of commercial ethylene oligomerisation catalysts ( $\mathrm{X}=$ appropriate anion).

In 2006, Tomov et al. reported a chromium bis(benzimidazole)methylamine (BIMA) complex which, in combination with MAO as the co-catalyst, generates a highly active ethylene oligomerisation catalyst with activities of $100,000 \mathrm{gmmol}^{-1} \mathrm{~h}^{-1} \mathrm{bar}^{-1} \cdot{ }^{20}$ An unusual alternating distribution of LAOs was obtained which was very different from Schulz-Flory or Poisson distributions. The $\alpha$-olefins formed from an odd number of ethylene units $(n=1,3$, 5 etc.) are significantly less abundant than the even-numbered oligomers such as 1-butene (n 
$=2)$, 1-octene $(n=4)$ and 1-dodecene $(n=6)$. An example of a chromatogram for a distribution obtained with a BIMA chromium catalyst is shown in Figure 2. Alternating distributions are still very rare and have only been observed with chromium-based catalysts, but are not exclusive to BIMA-type ligands. ${ }^{21}$

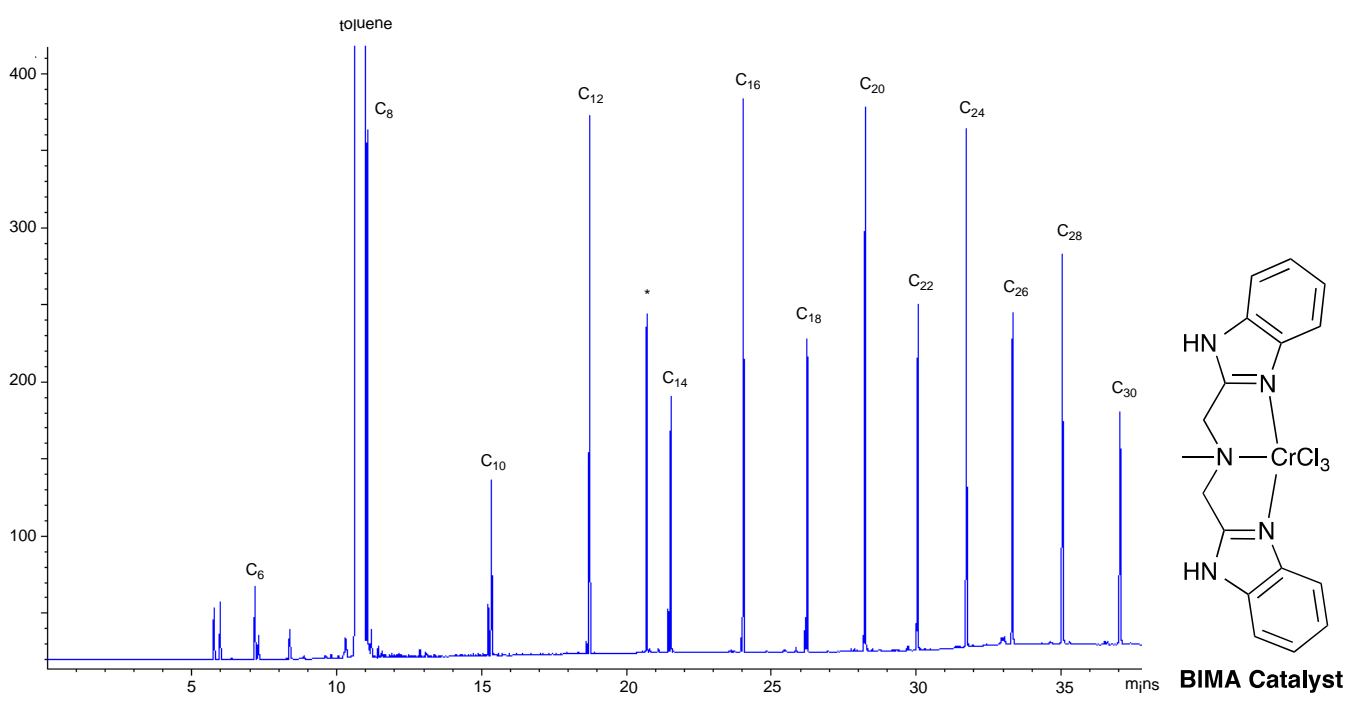

Figure 2. GC-FID analysis of an alternating olefin distribution obtained with chromium BIMA catalyst $\left[\mathrm{Cr}(2) \mathrm{Cl}_{3}\right] / \mathrm{MAO}$ (* = standard 2,2,4,4,6,8,8-heptamethyl nonane).

Here, we report a comprehensive study on these extremely active and remarkable chromium BIMA oligomerisation catalysts. The effects of different ligands, the coordination geometry around chromium, reaction parameters such as pressure and the nature of the cocatalyst on catalytic activity and product distribution have been investigated. Alternating distributions can be mathematically described by second order recurrence relations, which are related to first order recurrence relations, for example the Schulz-Flory distribution. ${ }^{22}$ Detailed analysis of the product distribution, including all side products, has led to a mechanistic proposal that involves a metallacyclic mechanism whereby both single and double ethylene insertion in the metallacycle are key steps in the oligomerisation process.

\section{Results and Discussion}

\section{Ligand and Complex Synthesis}

A series of nitrogen-based ligands 1-21 has been prepared, based on the original bis(benzimidazolemethyl)amine (BIMA) ligand 2 (see Figure 3). The synthesis and 
characterising data of ligands $2, \mathbf{6}, \mathbf{8}, \mathbf{9}, \mathbf{1 0}, \mathbf{1 1}, \mathbf{1 3}$ and $\mathbf{1 6},{ }^{23}$ as well as $\mathbf{4 , 5}$ and $\mathbf{1 2},{ }^{24,25}$ have been previously reported. The BIMA ligands $\mathbf{1}, \mathbf{1 4}$ and $\mathbf{1 5},{ }^{26}$ as well as $\mathbf{1 7},{ }^{27} \mathbf{2 0}^{28}$ and $\mathbf{2 1}{ }^{29}$ have been prepared by published methods and our ${ }^{1} \mathrm{H}$ NMR values agree with those reported previously. The extended ligands $\mathbf{1 8}$ and $\mathbf{1 9}$ were prepared according to a published procedure by condensation of phenylene diamine with 3,3'-iminodipropionitrile and our NMR data agreed with the data provided. ${ }^{30,31}$ The new ligands $\mathbf{3}$ and $\mathbf{7}$ were prepared by conventional condensation of phenylene diamine with $N$-alkyl iminodiacetic acid diethylester (see Experimental Section).
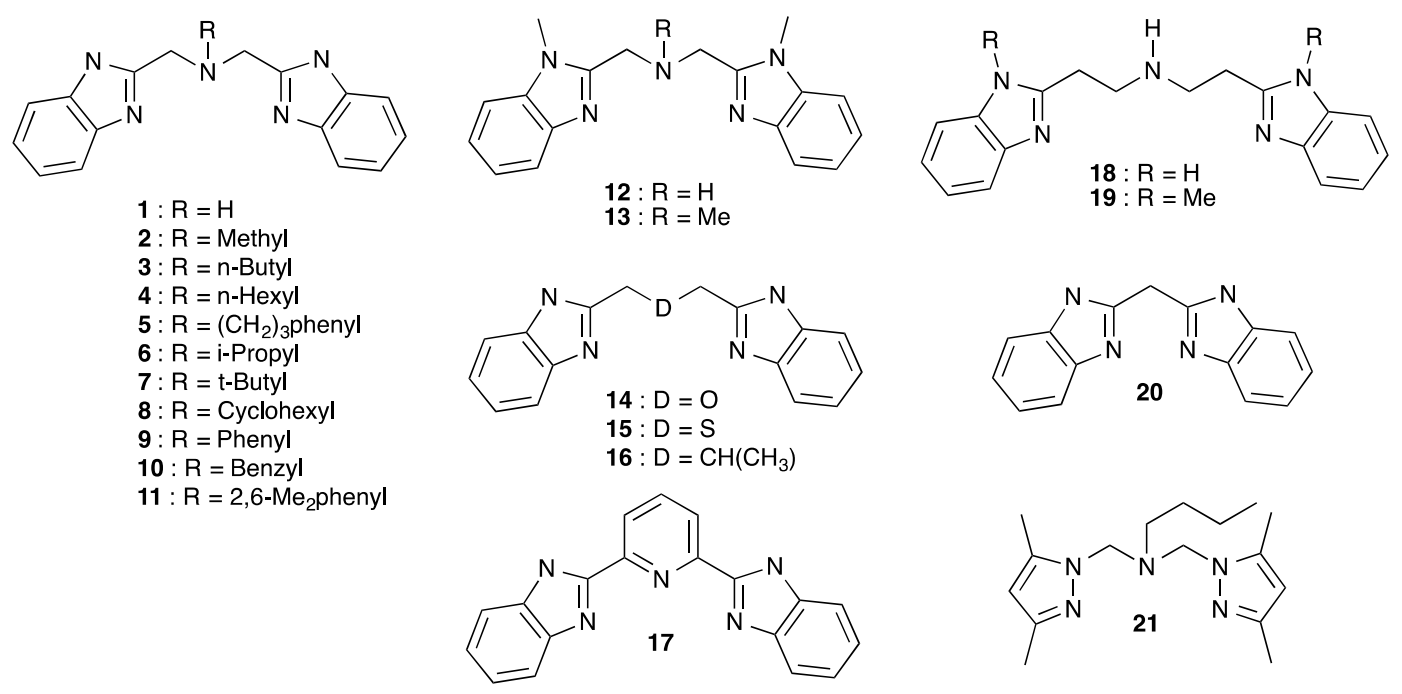

Figure 3. Overview of ligands $\mathbf{1}-\mathbf{2 1}$.

The syntheses and characterisation of complexes $\left[\operatorname{Cr}(\mathbf{2}) \mathrm{Cl}_{3}\right]^{20}$ and $\left[\operatorname{Cr}(\mathbf{1 7}) \mathrm{Cl}_{3}\right]^{27,32}$ have been described previously. All other chromium trichloride complexes $\left[\mathrm{Cr}(\mathbf{L}) \mathrm{Cl}_{3}\right]$ were prepared by combining equimolar amounts of $\left[\mathrm{CrCl}_{3}(\mathrm{thf})_{3}\right]$ and the relevant ligand in tetrahydrofuran. The resulting paramagnetic Cr(III) complexes were insoluble in most common organic solvents and were analysed by mass spectrometry, infra-red spectroscopy, magnetic susceptibility measurements and elemental analyses. X-ray analysis was carried out on crystals obtained from dimethylformamide (DMF) solutions for complexes $\left[\mathrm{Cr}(3) \mathrm{Cl}_{3}\right]$, $\left[\mathrm{Cr}(\mathbf{1 5}) \mathrm{Cl}_{3}\right]$ and $\left[\mathrm{Cr}(\mathbf{2 1}) \mathrm{Cl}_{3}\right]$. The structure of complex $\left[\mathrm{Cr}(3) \mathrm{Cl}_{3}\right]$ is shown in Figures S1516, whereas the latter two complexes are shown in Figure 4. In the case of ligand 5, the ionic complex $\left[\mathrm{Cr}(5) \mathrm{Cl}_{2}(\mathrm{dmf})\right] \mathrm{Cl}$ crystallised from a DMF solution, rather than the neutral complex $\left[\mathrm{Cr}(5) \mathrm{Cl}_{3}\right]$ (see Figure S21). 

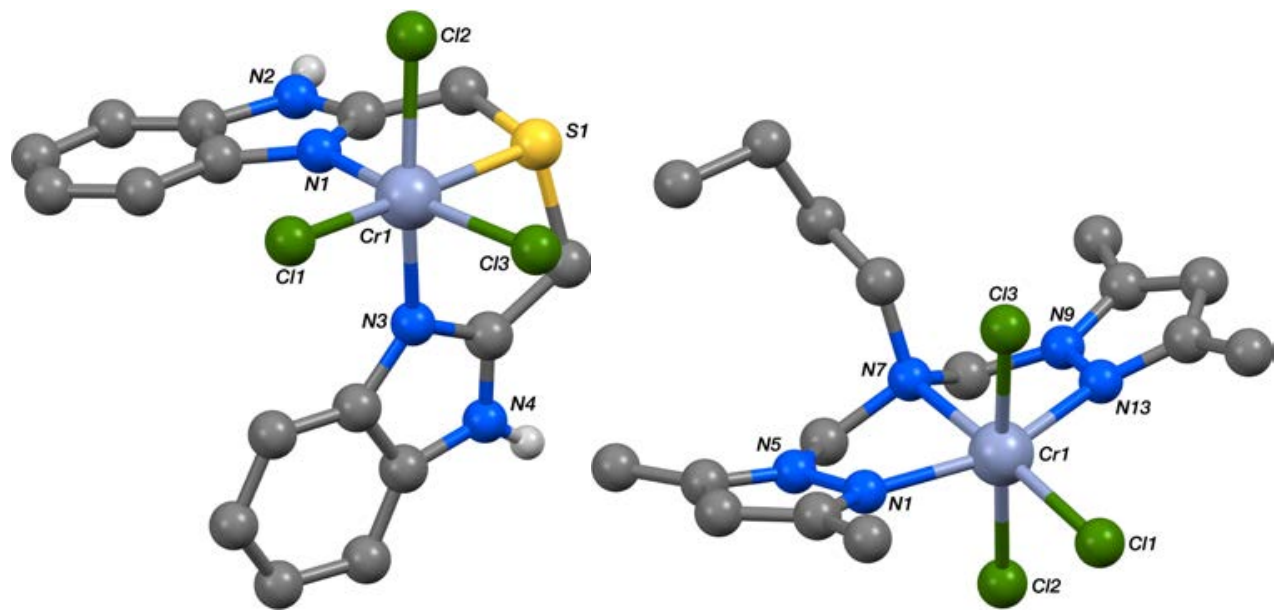

Figure 4. Molecular structures of the complexes fac- $\left[\mathrm{Cr}(\mathbf{1 5}) \mathrm{Cl}_{3}\right]$ and $\operatorname{mer}-\left[\mathrm{Cr}(\mathbf{2 1}) \mathrm{Cl}_{3}\right]$.

The poor solubility of the neutral complexes can be improved by their conversion into ionic complexes, for example with $\mathrm{AgSbF}_{6}$. This enabled isolation and crystallisation of the cationic complexes $\left[\mathrm{Cr}(\mathbf{1}) \mathrm{Cl}_{2}\left(\mathrm{OH}_{2}\right)\right]\left(\mathrm{SbF}_{6}\right)$ and $\left[\mathrm{Cr}(\mathbf{9}) \mathrm{Cl}_{2}(\mathrm{thf})\right]\left(\mathrm{SbF}_{6}\right)$, the molecular structures of which can be found in Figures S20 and 5, respectively. An alternative chromium source $\left[\mathrm{Cr}(\mathrm{CO})_{6}\right]$ was also investigated, which gave access to complex $\left[\mathrm{Cr}(2)(\mathrm{CO})_{3}\right]$ which was characterised by NMR and X-ray diffraction (see Figure 5). Chromium(0) carbonyl complexes with phosphine ligands have been oxidised with silver salts to chromium(I) complexes and used as catalyst precursors in ethylene oligomerisation. . $^{33,34}$

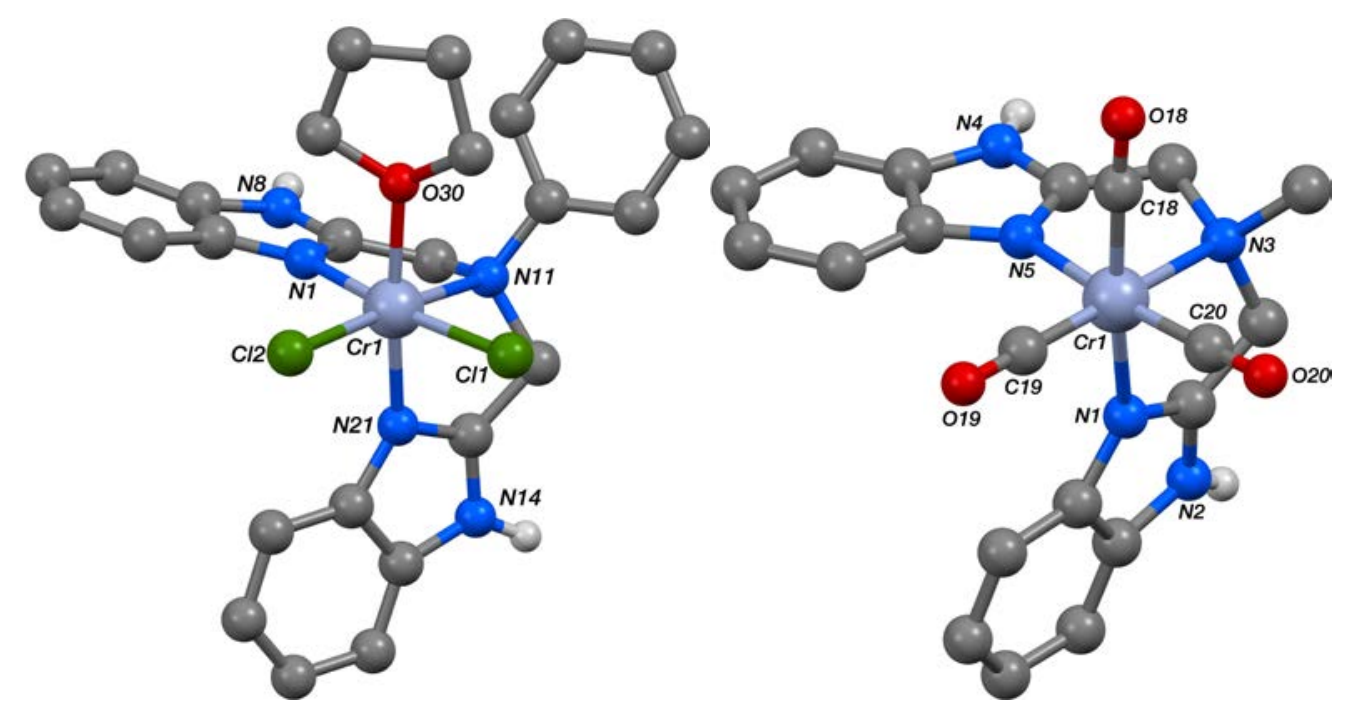

Figure 5. Molecular structures of the cationic complex fac- $\left[\mathrm{Cr}(\mathbf{9}) \mathrm{Cl}_{2}(\mathrm{thf})\right]\left(\mathrm{SbF}_{6}\right)\left(\mathrm{SbF}_{6}{ }^{-}\right.$ anion has been omitted for clarity) and $f a c-\left[\mathrm{Cr}(2)(\mathrm{CO})_{3}\right]$. 
Bis(benzimidazole) ligands generally adopt a facial (fac) coordination mode around the chromium centre, as seen previously in $\left[\mathrm{Cr}(2) \mathrm{Cl}_{3}\right]^{35}$ and here in complexes $\left[\mathrm{Cr}(3) \mathrm{Cl}_{3}\right]$, $\left[\mathrm{Cr}(\mathbf{1 5}) \mathrm{Cl}_{3}\right]$ and $\left[\mathrm{Cr}(2)(\mathrm{CO})_{3}\right]$, and in the cationic complexes $\left[\mathrm{Cr}(5) \mathrm{Cl}_{2}(\mathrm{dmf})\right] \mathrm{Cl}$, $\left[\mathrm{Cr}(\mathbf{9}) \mathrm{Cl}_{2}(\mathrm{thf})\right]\left(\mathrm{SbF}_{6}\right)$. The chloro ligand trans to one of the benzimidazole units is substituted in these fac complexes. Meridional (mer) coordination is less common and is seen with smaller ligands, for example in the bis(benzimidazole)amine complex $\left[\mathrm{Cr}(\mathbf{1}) \mathrm{Cl}_{2}\left(\mathrm{OH}_{2}\right)\right]\left(\mathrm{SbF}_{6}\right)$ and the bis(pyrazole)butylamine complex $\left[\mathrm{Cr}(\mathbf{2 1}) \mathrm{Cl}_{3}\right]$, suggesting that the size of the ligands may affect the coordination mode. The chloro ligand trans to the central amine donor is substituted in the cationic mer complex. The difference between the fac/mer coordination modes appears to be rather subtle, as both can be obtained with seemingly similar ligands. For example, the mer geometry is observed for the bis(pyrazole) amine ligand 21 in $\left[\mathrm{Cr}(\mathbf{2 1}) \mathrm{Cl}_{3}\right]$, whereas a fac mode has been reported for the very similar $\mathrm{N}$ methyl ligand. ${ }^{36}$ Furthermore, the same ligand can show different coordination modes in different complexes, for example ligand 2 coordinates in a fac mode in $\left[\mathrm{Cr}(2) \mathrm{Cl}_{3}\right]$, but a mer coordination is observed in $[\mathrm{Cr}(2) \mathrm{Cl}(\mathrm{acac})]\left(\mathrm{SbF}_{6}\right)$ when a bidentate acac ligand is employed. ${ }^{20,35}$

\section{Ethylene Oligomerisation Results}

The chromium(III) complexes $\left[\mathrm{Cr}(\mathbf{L}) \mathrm{Cl}_{3}\right]$, where $\mathbf{L}=\mathbf{1}-\mathbf{2 1}$ have been applied as catalysts for the oligomerisation of ethylene (Table 1). The liquid fractions have been analysed by FID-GC and the solid fractions by GPC in selected cases. For those catalysts that give an alternating olefin distribution, up to approximately $20 \mathrm{wt} \%$ of the total product collected is in the liquid phase, consisting of essentially pure $\mathrm{C}_{4}-\mathrm{C}_{38}$ LAOs. The gas phase contains predominantly ethylene and butene, which were not quantified. Solid polyethylene (80-100 wt\%) constitutes the remainder of the product spectrum and the fraction with $M_{n}$ values between 1000-2000 is the tail end of the overall LAO distribution. Based on several identical runs, the error in terms of activity and product selectivity values was estimated to be approximately 10\% (see Table S1 and Figure S7).

Table 1. Ethylene oligomerisation results with $\left[\mathrm{Cr}(\mathbf{L}) \mathrm{Cl}_{3}\right] / \mathrm{MAO}(\mathbf{L}=\mathbf{1} \mathbf{- 2 1})$. 


\begin{tabular}{|c|c|c|c|c|c|c|c|}
\hline Run & & & $\overline{\text { wt\% (LAO) }}$ & $\alpha$ & $\mathrm{M}_{\mathrm{n}}$ & $\mathrm{M}_{\mathrm{w}}$ & PDI \\
\hline 1 & {$\left[\mathrm{Cr}(\mathbf{1}) \mathrm{Cl}_{3}\right](0.03)$} & 15,000 & 18 (99) & & & & \\
\hline 2 & {$\left[\mathrm{Cr}(2) \mathrm{Cl}_{3}\right](0.03)$} & 102,000 & $21(99)$ & & 1,920 & 3,530 & 1.8 \\
\hline 3 & {$\left[\mathrm{Cr}(3) \mathrm{Cl}_{3}\right](0.03)$} & 96,000 & $11(97)$ & & 1,240 & 4,790 & 3.9 \\
\hline 4 & {$\left[\mathrm{Cr}(4) \mathrm{Cl}_{3}\right](0.03)$} & 97,000 & $6(92)$ & & 1,250 & 5,620 & 4.5 \\
\hline 5 & {$\left[\mathrm{Cr}(5) \mathrm{Cl}_{3}\right](0.03)$} & 39,000 & $12(97)$ & & 2,550 & 9,400 & 3.7 \\
\hline 6 & {$\left[\mathrm{Cr}(\mathbf{6}) \mathrm{Cl}_{3}\right](0.03)$} & 20,000 & $3(98)$ & & 7,710 & 127,710 & 16.6 \\
\hline 7 & {$\left[\mathrm{Cr}(7) \mathrm{Cl}_{3}\right](0.03)$} & 27,000 & 4 (99) & & 6,310 & 131,130 & 20.8 \\
\hline 8 & {$\left[\mathrm{Cr}(\mathbf{8}) \mathrm{Cl}_{3}\right](0.03)$} & 11,000 & 0 & & 8,890 & 158,700 & 17.9 \\
\hline 9 & {$\left[\mathrm{Cr}(\mathbf{9}) \mathrm{Cl}_{3}\right](0.03)$} & 11,000 & 5 (99) & & 3,930 & 92,830 & 23.7 \\
\hline 10 & {$\left[\mathrm{Cr}(\mathbf{1 0}) \mathrm{Cl}_{3}\right](0.03)$} & 5,000 & $17(98)$ & & 2,470 & 24,150 & 9.8 \\
\hline 11 & {$\left[\mathrm{Cr}(\mathbf{1 3}) \mathrm{Cl}_{3}\right](0.03)$} & 320 & nd & & & & \\
\hline 12 & {$\left[\mathrm{Cr}(\mathbf{1 4}) \mathrm{Cl}_{3}\right](0.3)$} & 2,200 & 11 & 0.95 & & & \\
\hline 13 & {$\left[\mathrm{Cr}(\mathbf{1 5}) \mathrm{Cl}_{3}\right](0.4)$} & 75 & 46 & 0.79 & & & \\
\hline 14 & {$\left[\mathrm{Cr}(\mathbf{1 6}) \mathrm{Cl}_{3}\right](2)$} & 770 & 92 & 0.55 & & & \\
\hline 15 & {$\left[\mathrm{Cr}(\mathbf{1 7}) \mathrm{Cl}_{3}\right](1)$} & 2,500 & $79(99)$ & 0.87 & $710^{\mathrm{b})}$ & & \\
\hline 16 & {$\left[\mathrm{Cr}(\mathbf{1 8}) \mathrm{Cl}_{3}\right](10)$} & 44 & 20 (99) & & & & \\
\hline 17 & {$\left[\mathrm{Cr}(\mathbf{1 9}) \mathrm{Cl}_{3}\right](10)$} & 21 & 9 (99) & 0.62 & & & \\
\hline 18 & {$\left[\mathrm{Cr}(\mathbf{2 0}) \mathrm{Cl}_{3}\right](5)^{\mathrm{a})}$} & 16 & 0 & & & & \\
\hline 19 & {$\left[\mathrm{Cr}(2) \mathrm{Cl}_{2}(\mathrm{thf})\right]\left(\mathrm{SbF}_{6}\right)(0.03)$} & 16,000 & $21(98)$ & & $1,200^{\mathrm{b})}$ & & \\
\hline 20 & {$\left[\mathrm{Cr}(\mathbf{9}) \mathrm{Cl}_{2}(\mathrm{thf})\right]\left(\mathrm{SbF}_{6}\right)(0.03)$} & 16,000 & 9 (99) & & $2,800^{\mathrm{b})}$ & & \\
\hline 21 & {$\left[\mathrm{CrCl}_{3}\left(\mathrm{thf}_{3}\right](25)^{\mathrm{c}}\right)$} & 88 & $96(99)$ & 0.54 & & & \\
\hline
\end{tabular}

Conditions: 4 bar ethylene pressure, $50{ }^{\circ} \mathrm{C}$, MAO (120 equiv.), toluene $200 \mathrm{~mL}, 1$ hour. Activity in gmmol ${ }^{-1} \mathrm{~h}^{-}$ ${ }^{1} \mathrm{bar}^{-1}$. a) 1 barg ethylene pressure. b) determined by ${ }^{1} \mathrm{H}$ NMR. c) 4 barg ethylene pressure, $50{ }^{\circ} \mathrm{C}$, MMAO- 12 (500 equiv.), toluene $100 \mathrm{~mL}, 1$ hour.

Extremely high activities in excess of $100,000 \mathrm{gmmol}^{-1} \mathrm{~h}^{-1} \mathrm{bar}^{-1}$ can be obtained with chromium BIMA complexes, for example ligands $\mathbf{2}-\mathbf{4}$ with n-alkyl substituents (Me, ${ }^{\mathrm{n}} \mathrm{Bu}$ or ${ }^{\mathrm{n}} \mathrm{Hex}$, runs 2-4). Catalytic activities are very sensitive to the nature of the substituent at the central amine. Complex $\left[\mathrm{Cr}(\mathbf{1}) \mathrm{Cl}_{3}\right]$ with a hydrogen substituent at the central nitrogen is significantly less active at 15,000 $\mathrm{gmmol}^{-1} \mathrm{~h}^{-1} \mathrm{bar}^{-1}$. More bulky substituents ( ${ }^{\mathrm{i}} \mathrm{Pr},{ }^{\mathrm{t}} \mathrm{Bu}, \mathrm{Cy}, \mathrm{Bz}$ and $\mathrm{Ph}$ ) at the central nitrogen donor in complexes $\left[\mathrm{Cr}(\mathbf{6}) \mathrm{Cl}_{3}\right]-\left[\mathrm{Cr}(\mathbf{1 0}) \mathrm{Cl}_{3}\right]$ lead to a reduced catalytic activity, less toluene-soluble olefins and progressively higher molecular weight polyethylene. The 2,6-dimethylphenyl complex $\left[\mathrm{Cr}(\mathbf{1 1}) \mathrm{Cl}_{3}\right]$ was inactive under these conditions and it is likely that the central amine is not coordinated in this case, as seen for an analogous cobalt(II) complex. ${ }^{23}$ The cationic complex $\left[\mathrm{Cr}(2) \mathrm{Cl}_{2}(\mathrm{thf})\right]\left(\mathrm{SbF}_{6}\right)$ shows a lower activity compared with $\left[\mathrm{Cr}(2) \mathrm{Cl}_{3}\right]$ (runs 2 and 19), ${ }^{20}$ whereas similar results are obtained for $\left[\mathrm{Cr}(\mathbf{9}) \mathrm{Cl}_{2}(\mathrm{thf})\right]\left(\mathrm{SbF}_{6}\right)$ versus $\left[\mathrm{Cr}(\mathbf{9}) \mathrm{Cl}_{3}\right]$ (runs 9 and 20). The catalyst precursor $\left[\mathrm{CrCl}_{3}(\mathrm{thf})_{3}\right]$ without any additional ligand gives a Schulz-Flory distribution with very low activity (run 21). It appears that small alkyl substituents such as methyl or higher linear alkyls at the 
central nitrogen provide an optimal donor strength, both sterically and electronically, for high catalytic activity.

Substitution at the benzimidazole nitrogens reduces the activity dramatically. For example, complex $\left[\mathrm{Cr}(\mathbf{1 3}) \mathrm{Cl}_{3}\right]$ with methylated benzimidazoles shows an activity of $320 \mathrm{gmmol}^{-1} \mathrm{~h}^{-}$ ${ }^{1} \mathrm{bar}^{-1}$. The related complex $\left[\mathrm{Cr}(\mathbf{1 2}) \mathrm{Cl}_{3}\right]$ with a central $\mathrm{NH}$ amine donor was inactive under the conditions used. Changing the central amine to other donors such as oxygen or sulfur in complexes $\left[\mathrm{Cr}(\mathbf{1 4}) \mathrm{Cl}_{3}\right]$ and $\left[\mathrm{Cr}(\mathbf{1 5}) \mathrm{Cl}_{3}\right]$ or a non-coordinating $\mathrm{CH}\left(\mathrm{CH}_{3}\right)$ unit in complex $\left[\mathrm{Cr}(\mathbf{1 6}) \mathrm{Cl}_{3}\right]$ reduces the activity significantly compared with $\left[\mathrm{Cr}(2) \mathrm{Cl}_{3}\right]$. Coordination of the central sulfur donor in $\left[\mathrm{Cr}(\mathbf{1 5}) \mathrm{Cl}_{3}\right]$ is confirmed by X-ray analysis (see Figure 4), but this coordination is weak judging from the long Cr-S distance of 2.415(3) A. Similarly, coordination of the central oxygen donor in complex $\left[\mathrm{Cr}(\mathbf{1 4}) \mathrm{Cl}_{3}\right]$ is unlikely, considering the very long metal oxygen distances seen in other complexes with this ligand. ${ }^{37,38}$ A strongly coordinating central donor appears to be essential for high catalytic activity and only $\mathrm{sp}^{3}$ hybridised amine donors result in an alternating olefin distribution. A $\mathrm{sp}^{2}$-hybridised nitrogen donor, such as pyridine in complex $\left[\operatorname{Cr}(\mathbf{1 7}) \mathrm{Cl}_{3}\right]$, shows a significantly lower activity and, more importantly, gives a Schulz-Flory distribution of LAOs with $\alpha=0.87$. $^{39}$ A SchulzFlory distribution is also observed for the distributions obtained with complexes $\left[\mathrm{Cr}(\mathbf{1 4}) \mathrm{Cl}_{3}\right]$ [Cr(16) $\mathrm{Cl}_{3}$ ], where $\alpha$ is $0.95,0.79$, and 0.55 respectively.

Extending the bridge between the central donor and the benzimidazole units with an extra methylene unit, as in $\left[\operatorname{Cr}(\mathbf{1 8}) \mathrm{Cl}_{3}\right]$, results in significantly lower activity compared with $\left[\mathrm{Cr}(\mathbf{1}) \mathrm{Cl}_{3}\right]$. The activity is further reduced for $\left[\mathrm{Cr}(\mathbf{1 9}) \mathrm{Cl}_{3}\right]$ with $N$-methylated benzimidazole units, as seen for $\left[\mathrm{Cr}(\mathbf{1 2}) \mathrm{Cl}_{3}\right]$ versus $\left[\mathrm{Cr}(\mathbf{1}) \mathrm{Cl}_{3}\right]$. Removal of the central donor in $\left[\mathrm{Cr}(\mathbf{2 0}) \mathrm{Cl}_{3}\right]$ or changing the benzimidazoles to pyrazole units in $\left[\operatorname{Cr}(21) \mathrm{Cl}_{3}\right]$ results in very low polymerisation activity. Similar activities have been reported for related chromium catalysts with bis(pyrazole)amine ligands, ${ }^{40,41}$ whereas selective ethylene trimerisation was reported with facially coordinating tridentate bis(pyrazolyl) ligands. ${ }^{42}$

\section{Distribution analysis}

Chain growth in ethylene oligomerisation can occur via different mechanisms, depending on the catalyst employed. For chromium complexes containing BIMA ligands, a metallacyclic mechanism is implicated based on deuterium labelling studies. ${ }^{20}$ If chain growth proceeds via the coordination and insertion of single ethylene monomers, a SchulzFlory distribution is obtained, as seen for example for the chromium complexes with ligands 
14-17 and 19 (see Table 1). Schulz-Flory distributions can be mathematically described as a first order linear homogeneous recurrence relation with constant coefficients and the solution to this relation results in the typical Schulz-Flory equation: $\operatorname{mol}(\mathrm{n})=(1-\alpha) \alpha^{n-1} R$, where $n$ is the number of ethylene units in the oligomer and $R$ is the total molar amount of oligomers produced within the reaction time. The term $\alpha$ is the probability of chain propagation, which is defined by the rate of propagation divided by the sum of the rate of propagation and termination. The term $1-\alpha$ represents therefore the probability of chain termination. The $\operatorname{mol} \%$ fraction for each oligomer equals $\operatorname{mol} \%(\mathrm{n})=\operatorname{mol}(\mathrm{n}) / R=(1-\alpha) \alpha^{n-1} \cdot{ }^{43}$

Alternating LAO distributions, as obtained here with chromium complexes containing ligands 1-10, 13 and 18, can be mathematically described as a second order linear homogeneous recurrence relation with constant coefficients. ${ }^{43}$ Each oligomer fraction is related to the previous fraction and the one before by the parameters $\alpha$ and $\beta$ respectively, which are the probabilities of chain growth via single ethylene insertion $(\alpha)$ and double ethylene insertion $(\beta)$ (see Scheme 1). The term $1-\alpha-\beta$ represents the probability of termination.

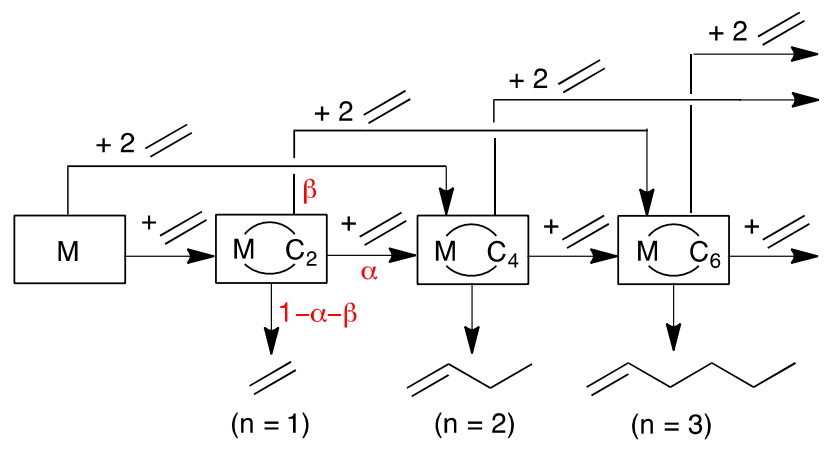

Scheme 1: Ethylene oligomerisation resulting in alternating distributions

The general solution to this recurrence relation takes the form mol(n) $=c_{1} r_{1}{ }^{n}+c_{2} r_{2}{ }^{n}$, whereby $c_{1,2}$ and $r_{1,2}$ are related to $\alpha$ and $\beta .^{43}$ Experimental data obtained for an alternating distribution can be fitted to this equation to determine $c_{1,2}$ and $r_{1,2}$, and thereby $\alpha$ and $\beta$ and $1-\alpha-\beta$. Data fitting analysis is performed using the $\mathrm{C}_{10}-\mathrm{C}_{34} \mathrm{LAO}$ fraction $(\mathrm{n}=5-17)$ and the goodness of fit is expressed by the $R^{2}$ values in the last column in Table 2. The $\mathrm{C}_{4}-\mathrm{C}_{8}$ oligomers are omitted because 1-butene $\left(\mathrm{C}_{4}\right)$ is too volatile for quantitative analysis and, as will be explained below, the experimental values for 1-hexene $\left(\mathrm{C}_{6}\right)$ and 1-octene $\left(\mathrm{C}_{8}\right)$ can 
sometimes deviate from the values calculated from the distribution analysis based on $\mathrm{C}_{10}-\mathrm{C}_{34}$. The analysis for a selection of distributions is collected in Table 2 and two graphical examples are shown in Figure 6. Other distributions can be found in the Supporting Information. For example, data fitting analysis of the oligomerisation results from $\mathrm{C}_{10}-\mathrm{C}_{34}$ for complex $\left[\mathrm{Cr}(4) \mathrm{Cl}_{3}\right]$ (run 4, Table 1) provides the equation mol\%(n) $=15.75(0.91)^{\mathrm{n}}+15.62(-$ $0.80)^{\mathrm{n}}$ for this particular distribution. The probabilities for single and double coordination are determined as $\alpha=0.11$ and $\beta=0.72$ and the probability for termination is $1-\alpha-\beta=0.17$.

Table 2. Analysis of alternating distributions. ${ }^{\mathrm{a}}$

\begin{tabular}{lllllllll}
\hline Catalyst & $\sum \operatorname{mmol}(\mathrm{n})^{\mathrm{b}}$ & $\operatorname{mol} \%(\mathrm{n})=c_{1} r_{1}{ }^{\mathrm{n}}+c_{2} r_{2}{ }^{\mathrm{n}}$ & $\alpha$ & $\beta$ & $1-\alpha-\beta$ & $\beta / \alpha$ & $c_{2} / c_{1}$ & $R^{2 \mathrm{c}}$ \\
\hline$\left[\mathrm{Cr}(\mathbf{1}) \mathrm{Cl}_{3}\right]$ & 0.82 & $18.77(0.89)^{\mathrm{n}}+3.64(-0.82)^{\mathrm{n}}$ & 0.07 & 0.72 & 0.21 & 10.2 & 0.19 & 0.998 \\
{$\left[\mathrm{Cr}(\mathbf{2}) \mathrm{Cl}_{3}\right]$} & 15.64 & $25.16(0.90)^{\mathrm{n}}+23.06(-0.79)^{\mathrm{n}}$ & 0.11 & 0.72 & 0.17 & 6.41 & 0.92 & 0.997 \\
{$\left[\mathrm{Cr}(\mathbf{4}) \mathrm{Cl}_{3}\right]$} & 18.94 & $15.75(0.91)^{\mathrm{n}}+15.62(-0.80)^{\mathrm{n}}$ & 0.11 & 0.72 & 0.17 & 6.55 & 0.99 & 0.997 \\
{$\left[\mathrm{Cr}(\mathbf{1 8}) \mathrm{Cl}_{3}\right]$} & 1.02 & $13.28(0.92)^{\mathrm{n}}+5.58(-0.87)^{\mathrm{n}}$ & 0.05 & 0.79 & 0.15 & 15.3 & 0.42 & 0.984
\end{tabular}

a) Conditions: see Table 1. b) Experimental total moles of LAOs from $\mathrm{n}=3-17$. c) $R^{2}$ signifies the goodness of fit of the calculated values compared with the experimental data.

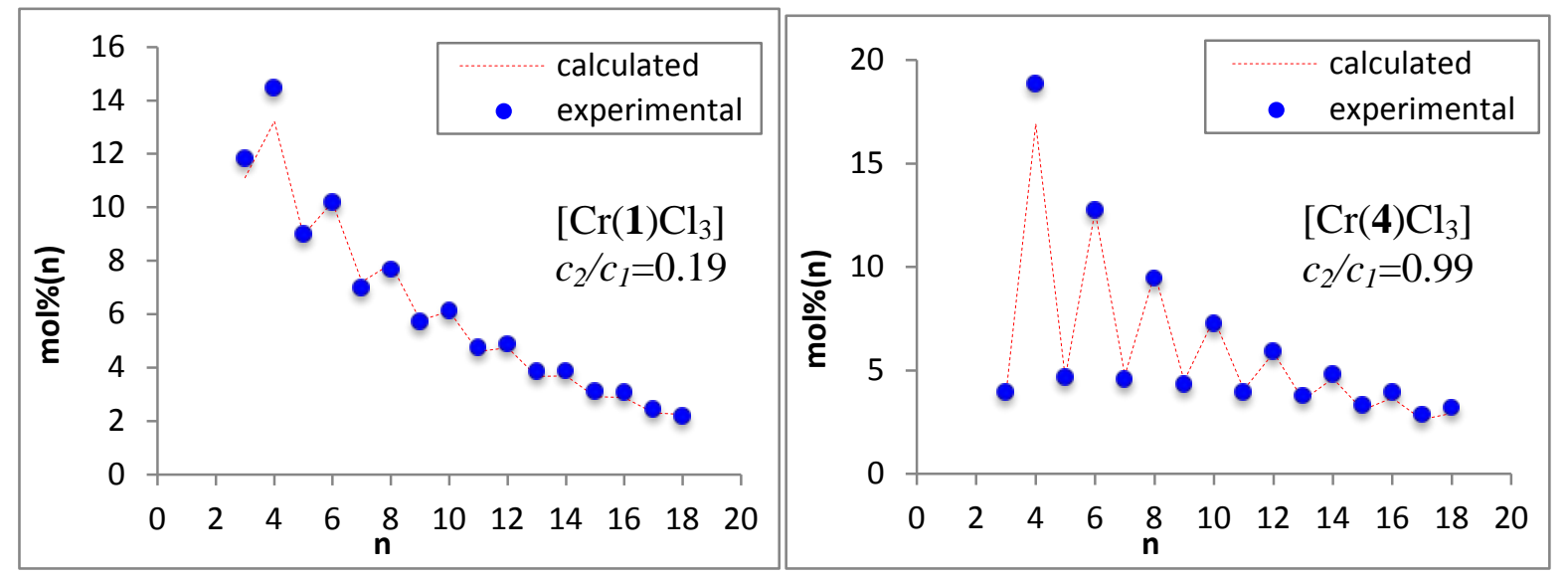

Figure 6. Experimental LAO distributions in mol\%(n) versus n obtained with $\left[\mathrm{Cr}(\mathbf{1}) \mathrm{Cl}_{3}\right]$ (left) and $\left[\mathrm{Cr}(4) \mathrm{Cl}_{3}\right]$ (right) together with calculated best-fit distributions ( $\mathrm{n}=$ number of ethylene units in oligomer).

The relation mol\%(n) $=c_{1} r_{1}{ }^{n}+c_{2} r_{2}{ }^{n}$ can be explained as an exponential decay function $c_{1} r_{1}{ }^{n}$ with a positive decay parameter $r_{1}$, combined with an alternating function $c_{2} r_{2}{ }^{n}$ with a negative parameter $r_{2}$. The relative importance of the various parameters $c_{1,2}$ and $r_{1,2}$ can be illustrated using the two examples shown in Figure 6. The $r_{1}$ and $r_{2}$ factors determine the steepness of the exponential decay functions. The degree of alternation is indicated by the 
weighting factors $c_{1}$ and $c_{2}$ and the ratio $c_{2} / c_{1}$ gives an indication of the extent of alternation. For example, for $\left[\mathrm{Cr}(\mathbf{1}) \mathrm{Cl}_{3}\right]$ the relatively small degree of alternation is indicated by the smaller value of $c_{2} / c_{1}=0.19$, whereas alternation is much more pronounced for $\left[\mathrm{Cr}(4) \mathrm{Cl}_{3}\right]$ where $c_{2} / c_{1}=0.99$.

In many cases, differences are observed between the experimental amounts obtained for 1hexene $\left(\mathrm{C}_{6}\right)$ and 1-octene $\left(\mathrm{C}_{8}\right)$ and those extrapolated from the $\mathrm{C}_{10}-\mathrm{C}_{34}$ distribution. These minor deviations are attributed to differences in the probabilities for metallacycle growth ( $\alpha$ and $\beta$ ) and termination $(1-\alpha-\beta)$ for smaller metallacycles early on in the oligomerisation process. These differences become negligible for larger metallacycles beyond metallacyclononane $\left(\mathrm{C}_{8}\right)$, and the propagation and termination probabilities converge to constant values. The small deviations observed here for $\mathrm{C}_{6}$ and $\mathrm{C}_{8}$ with chromium BIMA catalysts are probably related to other chromium-based catalysts where differences at the early stages of metallacycle growth lead to oligomerisations where 1-hexene or 1-octene become the major products of the distribution. ${ }^{43}$ This is for example observed with chromium-based selective oligomerisation catalysts.

\section{Effect of pressure}

Ethylene oligomerisation with catalyst $\left[\mathrm{Cr}(\mathbf{1 7}) \mathrm{Cl}_{3}\right]$, which contains a meridional ligand 17 with a central pyridine donor, results in a Schulz-Flory distribution of LAOs. ${ }^{39}$ The total oligomer yield obtained at different gauge pressures from 1-4 bar follows a first order dependence on ethylene concentration (see Figure S2). The order in ethylene concentration for individual LAOs is conveniently determined from the slope in a $\ln ($ rate) versus $\ln \left[\right.$ ethylene] plot, $^{44}$ whereby ethylene pressure is a reliable proxy for concentration in solution. ${ }^{44,45}$ The rate can be approximated by the amount of LAO produced within a given time. A first order dependence on ethylene pressure is observed for individual LAOs in this case and the difference for example between the orders for 1-octene and 1-hexene formation is very close to zero (see Figure S5). The LAO distribution is characterised by $\alpha=0.87$, which is independent of ethylene pressure within the pressure range from 1-4 bar. Because $\alpha$ is equal to the rate of propagation divided by the rate of propagation plus the rate of termination, this suggests that both the rate of propagation and the rate of termination are affected in a similar manner by ethylene concentration and that therefore chain transfer to monomer must be the main termination pathway (rather than $\beta$-H elimination). 
The effect of pressure on alternating distributions has been investigated for catalysts $\left[\mathrm{Cr}(\mathbf{1}) \mathrm{Cl}_{3}\right]$ and $\left[\mathrm{Cr}(\mathbf{4}) \mathrm{Cl}_{3}\right]$ at ethylene gauge pressures between 1-4 bar. The total yield of oligomers increases with a first order dependence on ethylene pressure in both cases (see Figures S3-S4). Figure 7 shows that the degree of alternation becomes more pronounced at higher pressure such that individual oligomers appear to have different orders in ethylene. Indeed, the difference between the orders for 1-octene and 1-hexene formation is distinctly non-zero (see Figure S6). The higher order for the formation of 1-octene with respect to 1hexene suggests a different mechanism involving both single and double insertions of ethylene in the case of 1-octene formation, whereas 1-hexene formation proceeds via single ethylene insertions only.

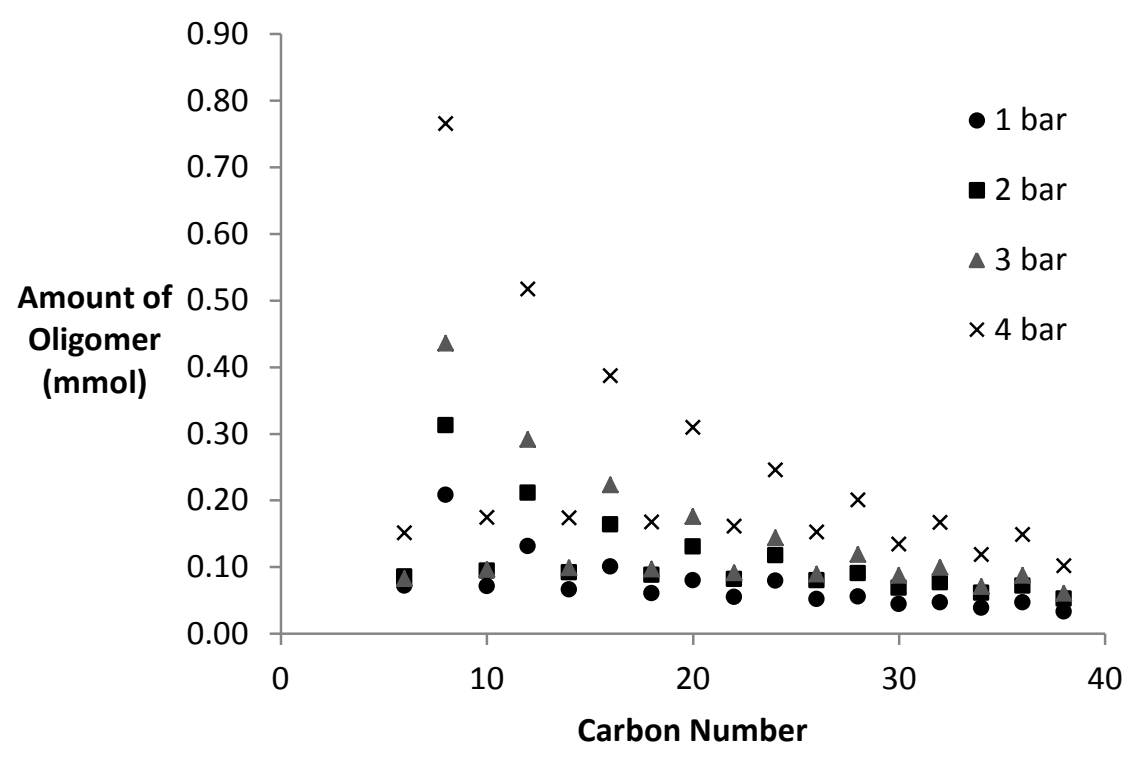

Figure 7. Pressure dependence of the LAO distribution with $\left[\operatorname{Cr}(4) \mathrm{Cl}_{3}\right]$. Conditions: see Table 3.

Table 3. Pressure dependence of the LAO distribution with $\left[\mathrm{Cr}(4) \mathrm{Cl}_{3}\right] / \mathrm{MAO}$.

\begin{tabular}{ccccccccc}
\hline $\mathrm{P}^{\mathrm{a})}$ & Olig./mmols $^{\mathrm{b}}$ & \multicolumn{1}{c}{$\mathrm{mol} \%(\mathrm{n})$} & $\alpha$ & $\beta$ & $1-\alpha-\beta$ & $\beta / \alpha$ & $c_{2} / c_{1}$ & $R^{2 \mathrm{c}}$ \\
\hline 1 barg & 1.24 & $13.23(0.92)^{\mathrm{n}}+9.93(-0.79)^{\mathrm{n}}$ & 0.13 & 0.73 & 0.14 & 5.77 & 0.75 & 0.979 \\
2 barg & 1.88 & $12.99(0.92)^{\mathrm{n}}+11.29(-0.81)^{\mathrm{n}}$ & 0.12 & 0.74 & 0.15 & 6.22 & 0.87 & 0.993 \\
3 barg & 2.35 & $13.79(0.92)^{\mathrm{n}}+14.18(-0.81)^{\mathrm{n}}$ & 0.11 & 0.75 & 0.16 & 6.93 & 1.03 & 0.996 \\
4 barg & 4.07 & $14.64(0.91)^{\mathrm{n}}+14.70(-0.81)^{\mathrm{n}}$ & 0.10 & 0.74 & 0.16 & 7.06 & 1.00 & 0.996 \\
\hline
\end{tabular}

Conditions: $\left[\mathrm{Cr}(4) \mathrm{Cl}_{3}\right] 30 \mathrm{nmol}, 50{ }^{\circ} \mathrm{C}, 1$ hour, $200 \mathrm{~mL}$ toluene, MAO (5 mmol). a) 1 barg (bar gauge) = 2 bara (bar absolute) $=1$ bar nitrogen +1 bar ethylene. b) Oligomers from $n=3-19$ c) $R^{2}$ signifies the goodness of fit of the calculated values compared with the experimental data. 
From Table 3 it appears that the ratio between the propagation probabilities for double versus single ethylene insertion $(\beta / \alpha)$ is pressure dependent. The increase in $\beta / \alpha$ shown in Figure 8 suggests that double insertion becomes more likely than single insertion at higher pressure. While the trend appears to be linear within this pressure regime, it is unclear at this stage whether this trend continues at higher or lower pressures.

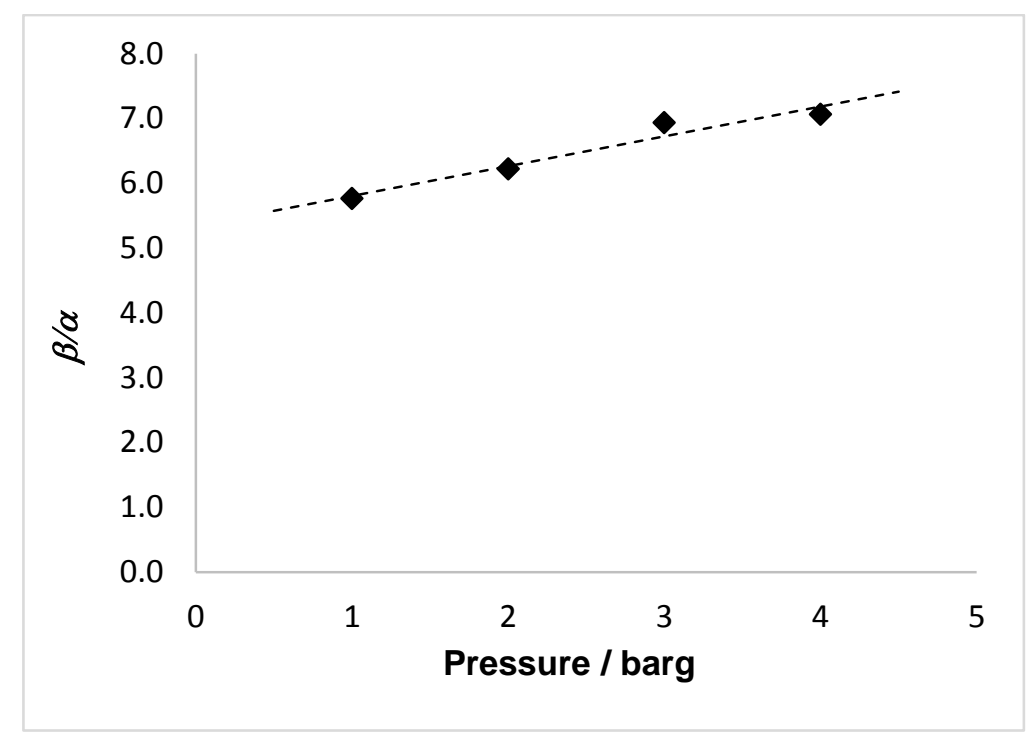

Figure 8. Dependence of $\beta / \alpha \square$ on ethylene gauge pressure. Trendline: linear $\left(\mathrm{R}^{2}=0.944\right)$. Conditions: catalyst $\left[\mathrm{Cr}(4) \mathrm{Cl}_{3}\right](30 \mathrm{nmol}), 50{ }^{\circ} \mathrm{C}, 1$ hour, $200 \mathrm{~mL}$ toluene, MAO (5 mmol).

\section{Effect of different co-catalysts}

Different co-catalysts have been evaluated in combination with BIMA catalyst $\left[\mathrm{Cr}(2) \mathrm{Cl}_{3}\right]$. All co-catalysts listed in Table 4 provide active catalyst systems and the activities can vary considerably. MAO provides the best activity, but yields the lowest amount of oligomers in the liquid fraction. The combination of an alkylating reagent $\left(\mathrm{AlMe}_{3}\right)$ with several abstracting reagents $\left(\mathrm{B}\left(\mathrm{C}_{6} \mathrm{~F}_{5}\right)_{3},\left[\mathrm{Ph}_{3} \mathrm{C}\right]\left[\mathrm{B}\left(\mathrm{C}_{6} \mathrm{~F}_{5}\right)_{4}\right]\right.$ or $\left.\left[\mathrm{PhNMe}{ }_{2} \mathrm{H}\right]\left[\mathrm{B}\left(\mathrm{C}_{6} \mathrm{~F}_{5}\right)_{4}\right]\right)$ gives somewhat lower activities, but a larger oligomer fraction. Somewhat surprisingly, $\mathrm{AlMe}_{3}$ without an abstractor also shows a reasonable activity with a comparable oligomer distribution. Experimental and calculated distributions can be found in Figures S8-12. While the differences between the distributions appear to be small, given the $10 \%$ error margin (see Table S1), we do believe they are significant. It appears that the nature of the co-catalyst can affect the oligomer distribution to some degree and that a trialkyl aluminium in general is an 
important aspect of the co-catalyst, something that will be discussed in more detail in the last section.

Table 4. Effect of different co-catalysts on the oligomer distribution with $\left[\mathrm{Cr}(2) \mathrm{Cl}_{3}\right]$.

\begin{tabular}{|c|c|c|c|c|c|c|c|c|}
\hline Co-catalyst & Act. $^{a}$ & $\begin{array}{l}\text { Liq. } \\
\text { wt } \%\end{array}$ & mol\%(n) & $\alpha$ & $\beta$ & $1-\alpha-\beta$ & $\beta / \alpha$ & $\mathrm{R}^{2}$ \\
\hline MAO & 18,500 & 8 & $17.60(0.89)^{\mathrm{n}}+19.03(-0.77)^{\mathrm{n}}$ & 0.12 & 0.69 & 0.20 & 5.92 & 0.994 \\
\hline $\mathrm{B}\left(\mathrm{C}_{6} \mathrm{~F}_{5}\right)_{3} / \mathrm{AlMe}_{3}$ & 8,000 & 32 & $17.81(0.89)^{\mathrm{n}}+10.61(-0.76)^{\mathrm{n}}$ & 0.13 & 0.68 & 0.20 & 5.39 & 0.998 \\
\hline$\left[\mathrm{Ph}_{3} \mathrm{C}\right]\left[\mathrm{BAr}^{\mathrm{F}}\right] / \mathrm{AlMe}_{3}$ & 12,000 & 35 & $18.02(0.89)^{\mathrm{n}}+16.30(-0.74)^{\mathrm{n}}$ & 0.15 & 0.66 & 0.19 & 4.49 & 0.999 \\
\hline$\left[\mathrm{PhNMe}_{2} \mathrm{H}\right]\left[\mathrm{BAr}^{\mathrm{F}}\right] / \mathrm{AlMe}_{3}$ & 13,200 & 46 & $21.10(0.87)^{\mathrm{n}}+15.39(-0.79)^{\mathrm{n}}$ & 0.09 & 0.69 & 0.22 & 8.00 & 0.998 \\
\hline $\mathrm{AlMe}_{3}$ & 4,800 & 32 & $18.07(0.89)^{\mathrm{n}}+17.11(-0.72)^{\mathrm{n}}$ & 0.16 & 0.64 & 0.20 & 3.91 & 0.996 \\
\hline
\end{tabular}

Conditions: catalyst $\left[\mathrm{Cr}(2) \mathrm{Cl}_{3}\right] 0.5 \mu \mathrm{mol}, 4 \mathrm{barg}, 1$ hour, $50{ }^{\circ} \mathrm{C}, 200 \mathrm{~mL}$ toluene. a) Activity in $\mathrm{gmmol}^{-1} \mathrm{~h}^{-1} \mathrm{bar}^{-1}$. Co-catalysts: MAO: 3 mmol (6000 equiv.); $\mathrm{B}\left(\mathrm{C}_{6} \mathrm{~F}_{5}\right)_{3},\left[\mathrm{Ph}_{3} \mathrm{C}\right]\left[\mathrm{BAr}^{\mathrm{F}}\right]$ and $\left[\mathrm{PhNMe}_{2} \mathrm{H}\right]\left[\mathrm{BAr}{ }^{\mathrm{F}}\right]: 0.5 \mathrm{mmol}$ (1 equiv.) and $\mathrm{AlMe}_{3}: 0.5 \mathrm{mmol}\left(1000\right.$ equiv.) $\left[\mathrm{BAr}^{\mathrm{F}}\right]^{-}=\left[\mathrm{B}\left(\mathrm{C}_{6} \mathrm{~F}_{5}\right)_{4}\right]^{-}$.

\section{Side products}

The selectivity for the formation of LAOs obtained with chromium BIMA catalysts is generally very high, typically in excess of 95\% (see Table 1). In addition to the main LAO distribution, a second minor distribution can sometimes be observed, depending on the reaction conditions. This minor distribution follows the opposite alternating pattern compared to the main distribution, i.e. oligomers derived from an odd number of ethylene units are more abundant than those from an even number, as can be seen in Figure 2 . Because 1-butene is the major product in these oligomerisation reactions, the second minor distribution is generated from incorporation of 1-butene into the oligomerisation reaction, as shown in Equations 2 and 3. This was confirmed by oligomerisation experiments of ethylene with additional 1-butene, using catalyst $\left[\mathrm{Cr}(2) \mathrm{Cl}_{3}\right]$ (Table 5). In the absence of 1-butene, the wt\% ratio between the major and minor fraction is approximately $17: 1$, which changes to $5: 1$ upon addition of an excess of 1-butene. The identity of the minor products was confirmed as a distribution of 2-ethyl-1-alkenes, based on NMR and GC analysis (see Figure S13) and comparison with an authentic sample of the $C_{6}$ product 2-ethyl-1-butene ( $m=1$ in Eq. 3). Co-oligomerisation of ethylene with higher 1-alkenes is known to occur with chromium-type oligomerisation catalysts that operate via a metallacyclic mechanism. ${ }^{19,46-49}$ 


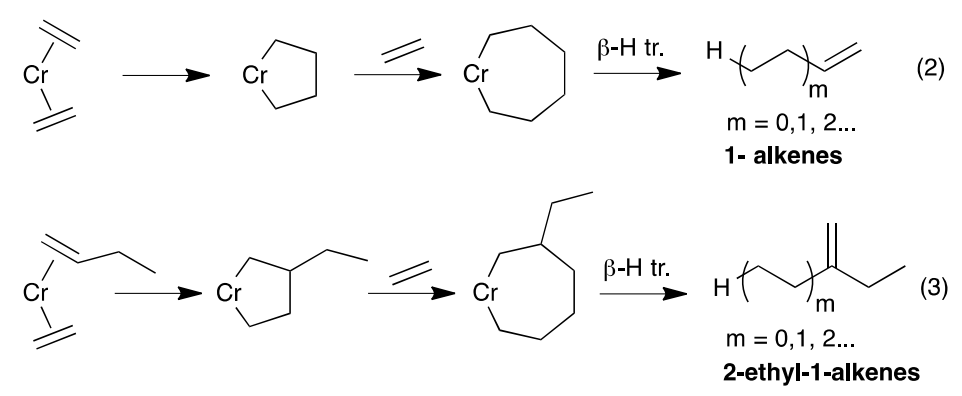

The activity of the catalyst system $\left[\mathrm{Cr}(2) \mathrm{Cl}_{3}\right] / \mathrm{MAO}$ decreases significantly from 54,900 to $8,400 \mathrm{gmmol}^{-1} \mathrm{~h}^{-1} \mathrm{bar}^{-1}$ upon addition of a large excess of 1-butene. Additional 1-butene is likely to slow down the rate of oligomerisation due to coordination to the metal centre, which will require substitution by ethylene before metallacycle growth can proceed. No oligomers due to the oligomerisation of 1-butene alone are observed.

The distribution of the major 1-alkene fraction differs from the 2-ethyl-1-alkene fraction in that, aside from the opposite alternating behaviour, the probability for termination $(1-\alpha-\beta)$ is significantly higher for the latter, $c f .0 .36$ versus 0.22 (0.28 versus 0.22 with additional 1 butene). As a result, the amount of 2-ethyl-1-alkene isomer produced will decrease more rapidly than the amount of 1-alkene and therefore the selectivity to 1-alkenes will increase across the product distribution. Termination via $\beta-\mathrm{H}$ transfer is expected to be faster for weaker tertiary $\mathrm{C}-\mathrm{H}$ bonds in the 2-ethyl metallacyclic complex in Eq. 3. The addition of 1butene affects the distribution in the 1-alkene and 2-ethyl-1-alkene fractions, as seen from the $\beta / \alpha$ ratios, which decrease from 5.89 to 3.99 and from 9.30 to 4.59 , respectively. Different distributions for both fractions imply that 1-butene incorporation into the metallacycle affects the distribution and 1-butene must therefore be incorporated at the beginning of metallacycle formation and not at the end. A stronger binding of 1-butene, but lower reactivity compared to ethylene provides an explanation for the observed behaviour. These observations made here for 1-butene may also apply to other 1-alkenes and implies a general inhibition of the oligomerisation reaction by the higher alkene products.

Table 5. Effect of addition of 1-butene on the 1-alkene and 2-ethyl-1-alkene distributions with $\left[\mathrm{Cr}(2) \mathrm{Cl}_{3}\right] / \mathrm{MAO}$.

\begin{tabular}{lcccccccc}
\hline & Act. $^{\mathrm{c}}$ & $\mathrm{wt}^{\mathrm{d})}$ & $\mathrm{mol}^{\mathrm{n}}(\mathrm{n})^{\mathrm{e}}$ & $\alpha$ & $\beta$ & $1-\alpha-\beta$ & $\beta / \alpha$ & $R^{2}$ \\
\hline 1-alkenes $^{\mathrm{a})}$ & 55,900 & 17 & $21.04(0.88)^{\mathrm{n}}+20.58(-0.76)^{\mathrm{n}}$ & 0.11 & 0.67 & 0.22 & 5.89 & 0.996 \\
2-ethyl-1-alkenes $^{\mathrm{a})}$ & & 1 & $36.16(0.79)^{\mathrm{n}}+26.39(-0.73)^{\mathrm{n}}$ & 0.06 & 0.58 & 0.36 & 9.30 & 0.999 \\
\hline 1-alkenes $^{\mathrm{b})}$ & 8,400 & 29 & $22.45(0.87)^{\mathrm{n}}+24.85(-0.71)^{\mathrm{n}}$ & 0.16 & 0.62 & 0.22 & 3.99 & 0.996 \\
2-ethyl-1-alkenes $^{\mathrm{b})}$ & & 6 & $23.97(0.83)^{\mathrm{n}}+27.14(-0.71)^{\mathrm{n}}$ & 0.13 & 0.59 & 0.28 & 4.59 & 0.999 \\
\hline
\end{tabular}


a) Conditions: catalyst $\left[\mathrm{Cr}(2) \mathrm{Cl}_{3}\right](30 \mathrm{nmol}), \operatorname{MAO}(7 \mathrm{mmol}), 4 \mathrm{bar}, 1$ hour, $50{ }^{\circ} \mathrm{C}, 200 \mathrm{~mL}$ toluene. b) Conditions: $\left[\mathrm{Cr}(2) \mathrm{Cl}_{3}\right] 150 \mathrm{nmol}$, MAO (7 mmol), 4 bar, 1 hour, $50{ }^{\circ} \mathrm{C}, 200 \mathrm{~mL}$ toluene, 1-butene (3.5 g) added. c) Activity in gmmol $^{-1} \mathrm{~h}^{-1} \mathrm{bar}^{-1}$, includes 1-alkenes, 2-ethyl-1-alkenes and polymer. d) weight percentage of olefins in the liquid fraction, remainder is solid polyethylene. e) 1-alkenes distribution: $n=1$ is ethylene, $n=2$ is 1-butene etc.; 2-ethyl-1-alkenes distribution: $\mathrm{n}=1$ is 1-butene, $\mathrm{n}=2$ is 2-ethyl-1-butene etc.

\section{Mechanistic considerations}

Single and double coordination mechanism

Chain growth in chromium-based BIMA catalysts proceeds via a metallacyclic mechanism. $^{39}$ A single coordination mechanism, i.e. coordination and insertion of a single ethylene unit at a time, results in a Schulz-Flory distribution, which is observed for example with chromium catalysts of ligands $14-\mathbf{1 7}$ that do not have a central amine donor. An alternating distribution is obtained via a double insertion mechanism, whereby two ethylene monomers coordinate to the chromium centre and insert sequentially. ${ }^{43}$ In this case, the termination probability after the first insertion is zero and the metallacycle effectively grows by two ethylene units at a time. The single and double insertion mechanisms can operate in parallel and the extent of each is determined by the probabilities $\alpha$ and $\beta$, which are affected by the catalyst, ethylene pressure, temperature, and the coordinating properties of the solvent and the anion (co-catalyst). We have previously established a double insertion route as the main mechanism in ethylene tetramerisation with Cr-PNP catalysts. $^{22}$

The growth of the metallacycle by single ethylene insertion requires a facial arrangment of the metallacyle and the ethylene monomer prior to insertion (Figure 9a). The insertion of two ethylene monomers requires double ethylene coordination. This arrangement can lead to the sequential insertion of two ethylene units without termination by $\beta-\mathrm{H}$ transfer after the first insertion. For each insertion step, the metallacycle and the ethylene monomer must be in facial orientation, as illustrated in Figure 9b. 


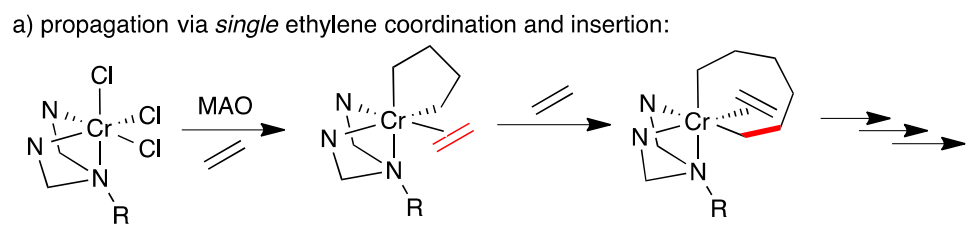

b) propagation via double ethylene coordination and insertion:

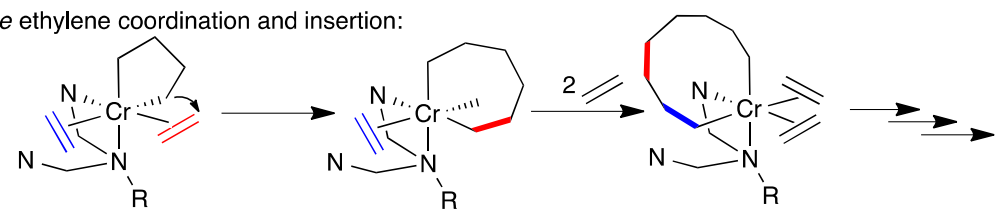

Figure 9. Metallacycle growth via (a) single and (b) double ethylene coordination and insertion.

Structural studies (vide infra) have shown that BIMA ligands can coordinate in a tridentate fac or mer fashion (see Figure 4) and a strong binding of the central donor was found to be essential for high catalytic activity. Coordination of two ethylene units to a chromium BIMA metallacyclic complex would generate a seven-coordinate complex, unless one of the donors dissociates. To explore this further, we investigated two related bidentate benzimidazole pyridine and benzimidazole amine ligands 22 and 23 (see Eq. 3). Combination of these ligands with $\left[\mathrm{CrCl}_{3}(\mathrm{thf})_{3}\right]$ is assumed to generate complexes of the type $\left[\mathrm{Cr}(\mathbf{L}) \mathrm{Cl}_{3}(\mathrm{thf})\right]$, as reported for similar bidentate nitrogen donor ligands. ${ }^{49-51}$ Very low activities were observed for both catalysts (see Table 6). Similar reduction in catalytic activity was observed by McGuinness with tridentate versus bidentate pyridine carbene ligands. ${ }^{49}$ The chromium complex with benzimidazole pyridine 22 resulted in a Schulz-Flory distribution of LAOs, similar to the oligomerisation with the bis(benzimidazole) pyridine ligand $\mathbf{1 7}$ (see Table 1, run 15). The distribution obtained with ligand 23 showed alternating behaviour (Table 6). Tridentate BIMA ligands clearly give a much better performance than the bidentate ligands 22 and 23. Notwithstanding, partial dissociation of one donor during metallacycle growth to provide the necessary coordination sites for two ethylene monomers, cannot be dismissed from these results.

Table 6. Alkene distributions with $\left[\mathrm{CrCl}_{3}(\operatorname{thf})_{3}\right] / 22, \quad\left[\mathrm{CrCl}_{3}(\operatorname{thf})_{3}\right] / 23$ and $\left[\mathrm{CrCl}_{3}(\mathrm{thf})_{3}\right] /\left[\left(\mathrm{AlMe}_{2}\right)_{2}\left(2^{\prime}\right)\right]_{3} \cdot{ }^{\text {a) }}$

\begin{tabular}{lcccccccc}
\hline & Act. & $\mathrm{wt}^{\mathrm{b}}{ }^{\mathrm{c}}$ & $\mathrm{mol} \%(\mathrm{n})^{\mathrm{d})}$ & $\alpha$ & $\beta$ & $1-\alpha-\beta$ & $\beta / \alpha$ & $R^{2}$ \\
\hline$[\mathrm{Cr}] / \mathbf{2 2}$ & 10 & 34 & $\mathrm{SF}$ & 0.62 & & & & 0.999 \\
{$[\mathrm{Cr}] / \mathbf{2 3}$} & 13 & 17 & $12.89(0.79)^{\mathrm{n}}+14.07(-0.63)^{\mathrm{n}}$ & 0.16 & 0.50 & 0.34 & 3.12 & 0.964 \\
{$[\mathrm{Cr}] /\left[\left(\mathrm{AlMe}_{2}\right)_{2}\left(2^{\prime}\right)\right]_{3}{ }^{\mathrm{e})}$} & 2,066 & 20 & $27.56(0.89)^{\mathrm{n}}+23.08(-0.80)^{\mathrm{n}}$ & 0.09 & 0.71 & 0.21 & 8.32 & 0.996 \\
\hline
\end{tabular}


a) Conditions: catalyst $[\mathrm{Cr}]=\left[\mathrm{CrCl}_{3}\left(\mathrm{thf}_{3}\right]\right.$ : $25 \mu \mathrm{mol}$, ligand 1 equiv., MMAO-12 (12.5 mmol), 4 bar, 1 hour, 50 ${ }^{\circ} \mathrm{C}, 100 \mathrm{~mL}$ toluene. b) Activity in $\mathrm{gmmol}^{-1} \mathrm{~h}^{-1} \mathrm{bar}^{-1}$, includes polymer. c) weight percentage of $\alpha$-olefins in the liquid phase. d) $\mathrm{SF}=$ Schulz-Flory distribution. e) $\left[\mathrm{CrCl}_{3}\left(\mathrm{thf}_{3}\right] /\left[\left(\mathrm{AlMe}_{2}\right)_{2}\left(2^{\prime}\right)\right]_{3}: 100 \mathrm{nmol}, \mathrm{MMAO}-12(24\right.$ mmol), 4 bar, 1 hour, $50{ }^{\circ} \mathrm{C}, 200 \mathrm{~mL}$ toluene.

The nature of the active species

It is very likely that during the activation of the BIMA pre-catalyst with the co-catalyst, which contains $\mathrm{AlMe}_{3}$, the benzimidazole $\mathrm{NH}$ functionalities become deprotonated to give anionic benzimidazolide ligands. This proposal is supported by a separate reaction carried out between BIMA ligand 2 and $\mathrm{AlMe}_{3}$ according to Equation 5. The reaction of 2 with two equivalents of $\mathrm{AlMe}_{3}$ in toluene resulted in deprotonation of both benzimidazole $\mathrm{NH}$ groups, followed by trimerisation to give a hexanuclear aluminium complex $\left[\left(\mathrm{AlMe}_{2}\right)_{2}(2 ')\right]_{3}$, which was characterised by NMR spectroscopy and X-ray diffraction (see Figure S22). Related cyclic aluminium benzimidazole complexes have been reported previously. ${ }^{52,53}$
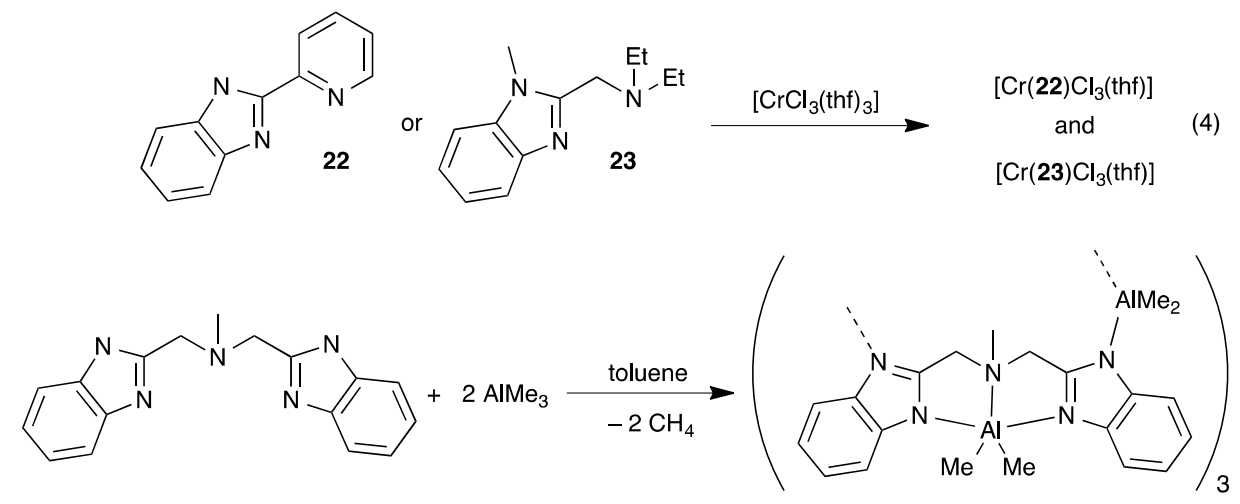

These observations suggest that the active species is generated upon reaction of the cocatalyst $\left(\mathrm{AlMe}_{3}\right)$ with the chromium trichloride pre-catalyst via deprotonation of the BIMA ligand. The requirement of $\mathrm{AlMe}_{3}$ in the co-catalyst seen earlier is in agreement with this proposal. A polymerisation reaction carried out using a combination of $\left[\left(\mathrm{AlMe}_{2}\right)_{2}\left(2^{\prime}\right)\right]_{3}$, $\left[\mathrm{CrCl}_{3}(\mathrm{thf})_{3}\right]$ and MAO resulted in a moderately active polymerisation system, giving an alternating distribution of LAOs (see Table 6).

The possibility of partial ligand dissociation was also investigated by DFT calculations. The relative free energy profile for a series of potential intermediates formed upon reaction of BIMA complex $\left[\mathrm{Cr}(2) \mathrm{Cl}_{3}\right]$ (I) with one or two equivalents of $\mathrm{AlMe}_{3}$ is shown in Figure 10. Deprotonation by two $\mathrm{AlMe}_{3}$ units (complexes VI-VIII) clearly shows a dramatic lowering of the relative energies, which suggests that a modifcation of the coordination environment 
around chromium upon addition of $\mathrm{AlMe}_{3}$ is very likely. Further studies on the nature of the active species are underway.
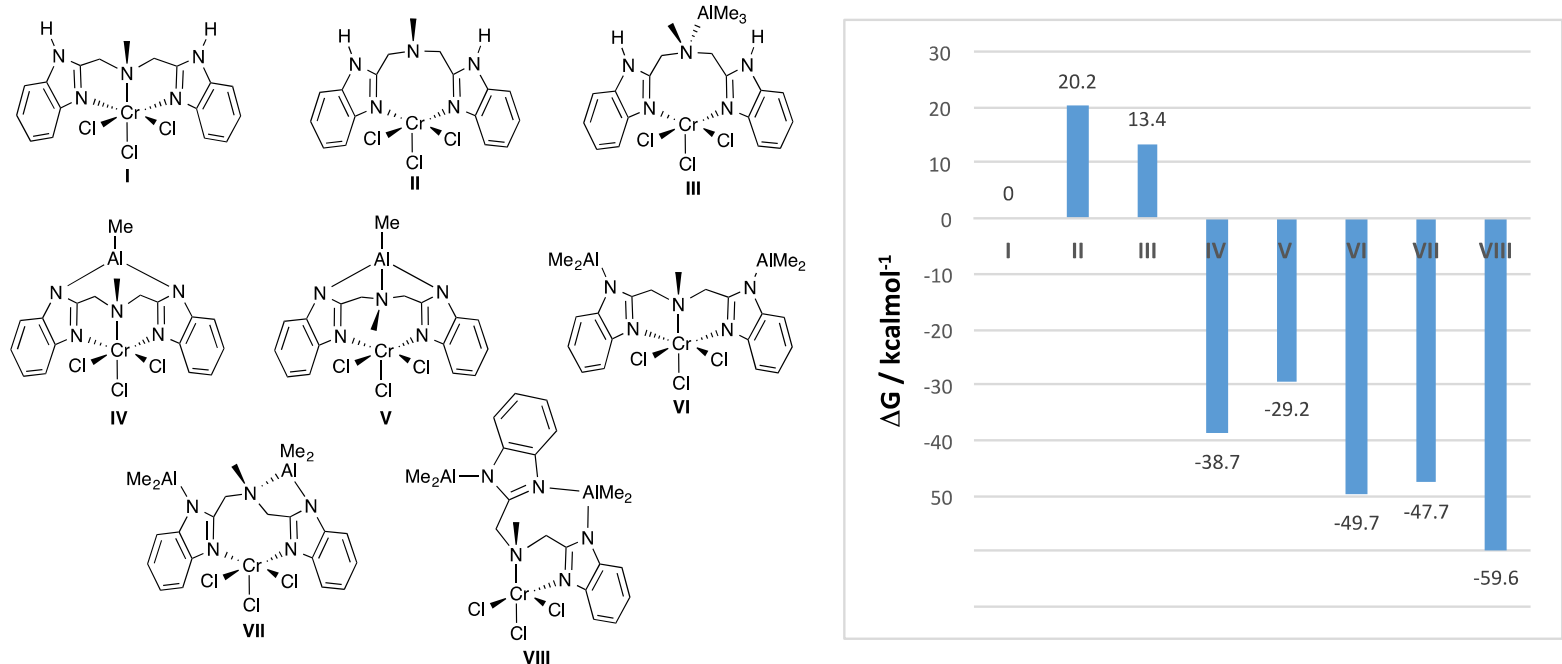

Figure 10. Relative Gibbs free energy profile of potential intermediates formed upon reaction of complex $\mathbf{I}$ with $\mathrm{AlMe}_{3}$. All energies are balanced for $\mathrm{AlMe}_{3}$ and, in the case of ligand deprotonation, $\mathrm{CH}_{4}$ formation. See Supporting Information for details.

In conclusion, chromium-based BIMA complexes are a class of ethylene oligomerisation catalysts that, depending on the ligand, can give extremely high catalytic activities and either a Schulz-Flory or an alternating distribution of LAOs in the liquid fraction, together with a major solid polyethylene fraction. Schulz-Flory distributions are described by a linear $1^{\text {st }}$ order recurrence relation with constant coefficient $\alpha$, whereas alternating distributions are mathematically described by a $2^{\text {nd }}$ order recurrence relation with constant coefficients $\alpha$ and $\beta$, which represent the probabilities for propagation via the insertion of one or two ethylene monomers, respectively. The $\beta / \alpha$ ratio increases with ethylene pressure within the range from 1-4 bar. A range of different co-catalysts can be used, which affect the catalytic activity and the LAO distribution. The presence of $\mathrm{AlMe}_{3}$ appears to be essential and it is believed to react with the facially coordinating BIMA ligand at the chromium centre. Incorporation of the most abundant LAO, 1-butene, can occur during the oligomerisation process, giving rise to a minor alternating distribution of 2-ethyl-1-alkenes with opposite alternating behaviour. Further studies to understand this intriguing class of oligomerisation catalysts, and our search for new catalysts which will generate as yet unseen oligomer distributions, continues.

\section{Experimental Section}

Synthesis of ligands 


\section{$N$-bis((1H-benzimidazol-2-yl)methyl)- $N$-n-butylamine (3)}

Compound 3 was synthesised using o-phenylenediamine (7.56 g, $70.6 \mathrm{mmol}$ ) and $\mathrm{N}, \mathrm{N}$ diethylacetate- $N$-butylamine $(8.66 \mathrm{~g}, 35.3 \mathrm{mmol})$. o-Phenylenediamine and the iminodiacetic acid ethyl ester were stirred at $190{ }^{\circ} \mathrm{C}$ for 4 hours. The water by-product was distilled from the reaction mixture which was then allowed to cool to room temperature. The product was triturated with water $(120 \mathrm{ml})$, filtered, washed with water $(4 \times 20 \mathrm{ml})$, recrystallised from hot methanol/water (1:30) and finally dried at $60{ }^{\circ} \mathrm{C}$ under vacuum for two days. Yield $5 \mathrm{~g}$ (43 \%). ${ }^{1} \mathrm{H}$ NMR (400 MHz, DMSO-d 6 , r.t.), $\delta 0.74$ (t, 3H, ${ }^{3} \mathrm{~J}_{\mathrm{HH}}$ 7.2, $\mathrm{CH}_{2} \mathrm{CH}_{3}$ ), 1.18 (sept, 2H, ${ }^{3} \mathrm{~J}_{\mathrm{HH}}=7.1, \mathrm{CH}_{2} \mathrm{CH}_{2} \mathrm{CH}_{3}$ ), 1.45 (quint, $2 \mathrm{H},{ }^{3} \mathrm{~J}_{\mathrm{HH}}$ 7.4, $\mathrm{CH}_{2} \mathrm{CH}_{2} \mathrm{CH}_{2}$ ), 2.5 (overlapping with solvent signal, $2 \mathrm{H}, \mathrm{CH}_{2}$ ), 3.97 (s, $4 \mathrm{H}, \mathrm{NCH}_{2} \mathrm{C}_{\mathrm{q}}$ ), 7.13-7.17 (m, 4H, $\mathrm{J}_{\mathrm{HH}}$ 3.1, ArH), 7.53-7.56 (m, 4H, J $\mathrm{HH}_{3.1}$, ArH). ${ }^{13} \mathrm{C}\left\{{ }^{1} \mathrm{H}\right\}$ NMR (100.6 MHz, DMSO-d 6 , r.t.) $\delta 13.8\left(\mathrm{CH}_{3}\right), 19.8$ $\left(\mathrm{CH}_{2} \mathrm{CH}_{3}\right), 28.5\left(\mathrm{CH}_{2} \mathrm{CH}_{2}\right), 52.1\left(\mathrm{NCH}_{2} \mathrm{C}_{\mathrm{q}}\right), 53.4\left(\mathrm{NCH}_{2} \mathrm{CH}_{2}\right), 114.8(\mathrm{ArC}), 121.5(\mathrm{ArC})$, 138.6 (ArC $C_{\text {ipso }}$ ), 152.68 (ArC ). Anal. Calc. for $\mathrm{C}_{20} \mathrm{H}_{23} \mathrm{~N}_{5}$ (F.W. 333.4) C 72.04, H 6.95, N 21.00 \%. Found C 71.87, H 7.07, N 20.83 \%. CI-MS (m/z); $334[\mathrm{M}+\mathrm{H}]^{+}, 362$.

\section{$N$-bis((1H-benzimidazol-2-yl)methyl)- $N$-tert-butylamine (7)}

Compound 7 was synthesised by an analogous procedure to that described for $\mathbf{3}$ using $o$ phenylenediamine (11.5 g, $106 \mathrm{mmol})$ and $N, N$-diethylacetate- $N$-tert-butylamine (13 g, 53 mmol). Yield 11.5 g (65 \%). ${ }^{1} \mathrm{H}$ NMR (400 MHz, DMSO-d 6 , r.t.), $\delta 1.09$ (s, $\left.\mathrm{CH}\left(\mathrm{CH}_{3}\right)_{2}\right), 4.00$ (s, $\left(\mathrm{NCH}_{2}\right.$ ), 4.10 (s, $\mathrm{NCH}_{2}$ ), 7.14 (broad m, ArH), 7.53 (broad m, ArH). ${ }^{13} \mathrm{C}\left\{{ }^{1} \mathrm{H}\right\} \mathrm{NMR}$ (100.6 MHz, DMSO-d 6 , r.t.) $\delta 26.1\left(\mathrm{CH}_{3}\right), 46.1\left(\mathrm{NCH}_{2} \mathrm{C}_{\mathrm{q}}\right), 54.4\left(\mathrm{NC}\left(\mathrm{CH}_{3}\right)_{3}\right), 115.2(\mathrm{ArC})$, $119.5(\operatorname{ArC}), 134.7$ ( $\left.\operatorname{ArC}_{\text {ipso }}\right), 152.8\left(\operatorname{Ar} C_{\mathrm{q}}\right)$. IR $\left(\mathrm{KBr}, \mathrm{cm}^{-1}\right), 3377(\mathrm{NH}, \mathrm{w}), 3054(\mathrm{Ar}-\mathrm{H}, \mathrm{s})$, 1683-1538 (ArC=C, C=N, m), 1456, 1436 (N-H, s), 1271 (CN, s), 749 (CH, s). Anal. Calc for $\mathrm{C}_{20} \mathrm{H}_{23} \mathrm{~N}_{5}$ (F.W. 333.4) C 72.04, H 6.95, N 21.00 \%. Found C 72.28, H 6.83, N 20.91 \%. CIMS $(\mathrm{m} / \mathrm{z}), 334[\mathrm{M}+\mathrm{H}]^{+}$.

Synthesis of chromium complexes

All Cr(III) complexes are paramagnetic and no NMR spectra could be recorded.

\section{$N, N$-bis((1H-benzimidazol-2-yl)methyl)amine chromium(III) chloride $\left[\mathrm{Cr}(1) \mathrm{Cl}_{3}\right]$}

Equimolar quantities of 1 (1 g, $3.61 \mathrm{mmol})$ and $\left[\mathrm{CrCl}_{3}(\mathrm{THF})_{3}\right]$ (1.35 g, $\left.3.61 \mathrm{mmol}\right)$ were stirred in $20 \mathrm{ml}$ of THF for 12 hours. The product was isolated by filtration, washed twice with THF (2 x $20 \mathrm{ml})$, once with diethyl ether (20 ml) and dried under vacuum. Yield $1.49 \mathrm{~g}$, 
95\%. Anal. Calc. for $\mathrm{C}_{16} \mathrm{H}_{15} \mathrm{Cl}_{3} \mathrm{CrN}_{5}$ (F.W. 435.7): C 44.11, H 3.47, N 16.07 \%. Found C 44.25, H 3.74, N 15.84 \%. IR (KBr, cm ${ }^{-1}$ ), 3202 (NH, s), 3120, 3110 (Ar-H, s), 1622-1544 $(\mathrm{ArC}=\mathrm{C}, \mathrm{C}=\mathrm{N}, \mathrm{m})$, 1497, 1477, $1456(\mathrm{~N}-\mathrm{H}, \mathrm{s}), 1278$ (CN, s), 743 (CH, s). UV-VIS (DMF): $\lambda_{\max } / \mathrm{nm}\left(\varepsilon_{\max } / \mathrm{dm}^{3} \mathrm{~mol}^{-1} \mathrm{~cm}^{-1}\right)=462$ (138), 635 (93), 721 (shoulder). FAB(+) MS ( $\left.\mathrm{m} / \mathrm{z}\right), 399$ $\left([\mathrm{M}-\mathrm{Cl}]^{+}\right), 363\left([\mathrm{M}-2 \mathrm{Cl}]^{+}\right) . \mu_{\mathrm{eff}}=3.77 \mathrm{BM}$.

\section{$N, N$-bis((1H-benzimidazol-2-yl)methyl)- $N$-methylamine chromium(III) chloride} $\left[\mathrm{Cr}(2) \mathrm{Cl}_{3}\right]$

Complex $\left[\mathrm{Cr}(2) \mathrm{Cl}_{3}\right]$ was synthesised by an analogous procedure to that described for [Cr(1) $\left.\mathrm{Cl}_{3}\right]$ using 2 (2 g, $\left.6.87 \mathrm{mmol}\right)$ and $\left[\mathrm{CrCl}_{3}(\mathrm{THF})_{3}\right]$ (2.57 g, $\left.6.87 \mathrm{mmol}\right)$. Yield $2.87 \mathrm{~g}$ (93 \%). Anal. Calc. for $\mathrm{C}_{17} \mathrm{H}_{17} \mathrm{Cl}_{3} \mathrm{Cr} \mathrm{N}_{5}$ (F.W. 449.7): C 45.40, H 3.81, N 15.57 \%. Found C 45.35, H 3.76, N 15.66 \%. IR ( $\left.\mathrm{KBr}, \mathrm{cm}^{-1}\right), 3221(\mathrm{NH}, \mathrm{s}), 1622-1544$ (ArC=C, C=N, m), 1497, 1477,1455 (N-H, s), 1274 (CN, s), 753 (CH, s). UV-VIS (DMF), $\lambda_{\max } / \mathrm{nm}\left(\varepsilon_{\max } / \mathrm{dm}^{3}\right.$ $\left.\left.\mathrm{mol}^{-1} \mathrm{~cm}^{-1}\right)\right)=464$ (156), 659 (75), 723 (shoulder). FAB(+) MS (m/z), 413 [M-Cl] $]^{+}, 291$ [M$\left.\mathrm{CrCl}_{3}\right]^{+} . \mu_{\mathrm{eff}}=3.87 \mathrm{BM}$.

\section{$N, N$-bis((1H-benzimidazol-2-yl)methyl)- $N$-butylamine chromium(III) chloride $\left[\mathrm{Cr}(3) \mathrm{Cl}_{3}\right]$}

Complex $\left[\mathrm{Cr}(3) \mathrm{Cl}_{3}\right]$ was synthesised by a procedure analogous to that described for [Cr(1) $\left.\mathrm{Cl}_{3}\right]$ using 3 (1 g, $\left.3.03 \mathrm{mmol}\right)$ and $\left[\mathrm{CrCl}_{3}(\mathrm{THF})_{3}\right](1.13 \mathrm{~g}, 3.61 \mathrm{mmol})$. Yield $1.49 \mathrm{~g}$, 84\%. Anal. Calc. for $\mathrm{C}_{20} \mathrm{H}_{23} \mathrm{Cl}_{3} \mathrm{CrN}_{5}$ (F.W. 491.8): C 48.85, H 4.71, N 14.24 \%. Found C 48.83, H 4.80, N 14.42 \%. IR (KBr, cm ${ }^{-1}$ ), 3440 (NH, m), 3229, 3077 (Ar-H, s), 1623-1549 $(\mathrm{ArC}=\mathrm{C}, \mathrm{C}=\mathrm{N}, \mathrm{m})$, 1499, 1477, 1454, 1433 (N-H, m, s), 1276 (CN, m), 762, 748 (CH, s). $\mathrm{FAB}(+) \mathrm{MS}(\mathrm{m} / \mathrm{z}), 455[\mathrm{M}-\mathrm{Cl}]^{+}, 420[\mathrm{M}-2 \mathrm{Cl}]^{+} . \mu_{\mathrm{eff}}=3.89 \mathrm{BM}$.

\section{$N, N$-bis((1H-benzimidazol-2-yl)methyl)- $N$-hexylamine chromium(III) chloride $\left[\mathrm{Cr}(4) \mathrm{Cl}_{3}\right]$}

Complex $\left[\mathrm{Cr}(4) \mathrm{Cl}_{3}\right]$ was synthesised by an analogous procedure to that described for [Cr(1)Cl $\left.)_{3}\right]$ using 4 (1 g, $\left.2.8 \mathrm{mmol}\right)$ and $\left[\mathrm{CrCl}_{3}(\mathrm{THF})_{3}\right]$ (1.05 g, $\left.2.8 \mathrm{mmol}\right)$. Yield $1.35 \mathrm{~g}, 93 \%$. Anal. Calc. for $\mathrm{C}_{22} \mathrm{H}_{27} \mathrm{Cl}_{3} \mathrm{CrN}_{5}$ (F.W. 519.8): C 50.83, H 5.24, N 13.47 \%. Found C 51.05, H 5.30, N 13.38 \%. IR (KBr, cm ${ }^{-1}$ ), 3502 (NH, m), 3228, 3073 (Ar-H, s), 1621-1542 (ArC=C, $\mathrm{C}=\mathrm{N}, \mathrm{m}), 1498,1477,1454,1431(\mathrm{~N}-\mathrm{H}, \mathrm{s}), 1273(\mathrm{CN}, \mathrm{m}), 752(\mathrm{CH}, \mathrm{s}) . \mathrm{FAB}(+) \mathrm{MS}(\mathrm{m} / \mathrm{z})$, $483[\mathrm{M}-\mathrm{Cl}]^{+}, 448[\mathrm{M}-2 \mathrm{Cl}]^{+}$. $\mu_{\mathrm{eff}}=3.83 \mathrm{BM}$. 
Complex $\left[\mathrm{Cr}(5) \mathrm{Cl}_{3}\right]$ was synthesised by an analogous procedure to that described for [Cr(1) $\left.\mathrm{Cl}_{3}\right]$ using $5(1 \mathrm{~g}, 2.53 \mathrm{mmol})$ and $\left[\mathrm{CrCl}_{3}(\mathrm{THF})_{3}\right](0.95 \mathrm{~g}, 2.53 \mathrm{mmol})$. Yield $1.00 \mathrm{~g}$ (71\%). Attempts to crystallise the complex from a solution in DMF resulted in crystals that were found to be the cationic complex [Cr(5) $\left.\mathrm{Cl}_{2}(\mathrm{dmf})\right] \mathrm{Cl}$. Anal. Calc. for $\mathrm{C}_{25} \mathrm{H}_{25} \mathrm{Cl}_{3} \mathrm{CrN}_{5}$ (F.W. 553.9): C 54.21, H 4.55, N 12.64 \%. Found C 54.32, H 4.79, N 12.50 \%. IR (KBr, cm ${ }^{-}$ $\left.{ }^{1}\right), 3231(\mathrm{NH}, \mathrm{s}), 1622-1543(\mathrm{ArC}=\mathrm{C}, \mathrm{C}=\mathrm{N}, \mathrm{m}), 1498,1477,1454(\mathrm{~N}-\mathrm{H}, \mathrm{s}), 1274(\mathrm{CN}, \mathrm{m})$, $752(\mathrm{CH}, \mathrm{s}) . \mathrm{FAB}(+) \mathrm{MS}(\mathrm{m} / \mathrm{z}), 517[\mathrm{M}-\mathrm{Cl}]^{+}, 482[\mathrm{M}-2 \mathrm{Cl}]^{+} . \mu_{\mathrm{eff}}=3.87 \mathrm{BM}$.

$N, N$-bis((1H-benzimidazol-2-yl)methyl)- $N$-(iso-propyl)amine chromium(III) chloride $\left[\mathrm{Cr}(\mathbf{6}) \mathrm{Cl}_{3}\right]$

Complex $\left[\mathrm{Cr}(\mathbf{6}) \mathrm{Cl}_{3}\right]$ was synthesised by an analogous procedure to that described for [Cr(1) $\left.\mathrm{Cl}_{3}\right]$ using 6 (0.432 g, $\left.1.35 \mathrm{mmol}\right)$ and $\left[\mathrm{CrCl}_{3}(\mathrm{THF})_{3}\right](0.51 \mathrm{~g}, 1.35 \mathrm{mmol})$. Yield $1.20 \mathrm{~g}$ (84\%). Anal. Calc. for $\mathrm{C}_{19} \mathrm{H}_{21} \mathrm{Cl}_{3} \mathrm{CrN}_{5}$ (F.W. 477.8): C 47.77, H 4.43, N 14.66 \%. Found C 47.87, H 4.35, N 14.46 \%. IR (KBr, cm $\left.{ }^{-1}\right), 3440,3226$ (NH, s), 3067 (Ar-H), 1622-1545 $(\mathrm{ArC}=\mathrm{C}, \mathrm{C}=\mathrm{N}, \mathrm{m})$, 1496, 1478, $1455(\mathrm{~N}-\mathrm{H}, \mathrm{s}, \mathrm{m}), 1275(\mathrm{CN}, \mathrm{m}), 752$ (CH, s). UV-VIS (DMF): $\lambda_{\max } / \mathrm{nm}=459,704,731$ (shoulder). $\mathrm{FAB}(+) \mathrm{MS}(\mathrm{m} / \mathrm{z}), 441[\mathrm{M}-\mathrm{Cl}]^{+}, 406[\mathrm{M}-2 \mathrm{Cl}]^{+}$, $368[\mathrm{M}-3 \mathrm{Cl}]^{+}, 320\left[\mathrm{M}-\mathrm{CrCl}_{3}\right]^{+} . \mu_{\mathrm{eff}}=3.46 \mathrm{BM}$.

$N, N$-bis((1H-benzimidazol-2-yl)methyl)- $N$-(tert-butyl)amine chromium(III) chloride $\left[\mathrm{Cr}(7) \mathrm{Cl}_{3}\right]$

Complex $\left[\mathrm{Cr}(7) \mathrm{Cl}_{3}\right]$ was synthesised by an analogous procedure to that described for [Cr(1) $\left.\mathrm{Cl}_{3}\right]$ using 7 (1 g, $\left.3.00 \mathrm{mmol}\right)$ and $\left[\mathrm{CrCl}_{3}(\mathrm{THF})_{3}\right](1.01 \mathrm{~g}, 3.00 \mathrm{mmol})$. Yield $1.15 \mathrm{~g}$ (78 \%). Anal. Calc. for $\mathrm{C}_{20} \mathrm{H}_{23} \mathrm{Cl}_{3} \mathrm{CrN}_{5}$ (F.W. 491.8): C 48.85, H 4.71, N 14.24 \%. Found C 48.97, H 4.90, N 14.37 \%. IR (KBr, cm ${ }^{-1}$ ), 3463 (NH, m), 3192, 3066 (Ar-H, s), 1653-1559 $(\mathrm{ArC}=\mathrm{C}, \mathrm{C}=\mathrm{N}, \mathrm{m}), 1497,1477,1455(\mathrm{~N}-\mathrm{H}, \mathrm{m}, \mathrm{s}), 1275(\mathrm{CN}, \mathrm{m}), 747(\mathrm{CH}, \mathrm{s}) . \mathrm{FAB}(+) \mathrm{MS}$ $(\mathrm{m} / \mathrm{z}), 455[\mathrm{M}-\mathrm{Cl}]^{+}, 420[\mathrm{M}-2 \mathrm{Cl}]^{+}, 334\left[\mathrm{M}-\mathrm{CrCl}_{3}\right]^{+} . \mu_{\mathrm{eff}}=3.93 \mathrm{BM}$.

$N, N$-bis((1H-benzimidazol-2-yl)methyl)- $N$-(cyclohexyl)amine chromium(III) chloride $\left[\mathrm{Cr}(\mathbf{8}) \mathrm{Cl}_{3}\right]$

Complex $\left[\mathrm{Cr}(\mathbf{8}) \mathrm{Cl}_{3}\right]$ was synthesised by an analogous procedure to that described for $\left[\mathrm{Cr}(\mathbf{1}) \mathrm{Cl}_{3}\right]$ using $8(1 \mathrm{~g}, 2.79 \mathrm{mmol})$ and $\left[\mathrm{CrCl}_{3}(\mathrm{THF})_{3}\right](1.04 \mathrm{~g}, 2.79 \mathrm{mmol})$. Yield $1.07 \mathrm{~g}$ 
(74\%). Anal. Calc. for $\mathrm{C}_{22} \mathrm{H}_{25} \mathrm{Cl}_{3} \mathrm{CrN}_{5}$ (F.W. 517.8): C 51.03, H 4.87, N $13.52 \%$. Found C 50.93, H 4.72, N 13.64 \%. IR (KBr, cm ${ }^{-1}$ ), 3252 (NH, s), 3060 (Ar-H, s), 1622-1538 $(\mathrm{ArC}=\mathrm{C}, \mathrm{C}=\mathrm{N}, \mathrm{m})$, 1496, 1477, $1454(\mathrm{NH}, \mathrm{s}, \mathrm{m}), 1276$ (CN, m), 749 (CH, s). UV-VIS (DMF), $\lambda_{\max } / \mathrm{nm}\left(\varepsilon_{\max } / \mathrm{dm}^{3} \mathrm{~mol}^{-1} \mathrm{~cm}^{-1}\right)=459$ (160), 704 (65), 731 (shoulder). FAB(+) MS $(\mathrm{m} / \mathrm{z}), 481[\mathrm{M}-\mathrm{Cl}]^{+}, 446[\mathrm{M}-2 \mathrm{Cl}]^{+}, 360\left[\mathrm{M}-\mathrm{CrCl}_{3}\right]^{+} . \mu_{\mathrm{eff}}=3.87 \mathrm{BM}$.

\section{$N, N$-bis((1H-benzimidazol-2-yl)methyl)- $N$-(phenyl)amine chromium(III) chloride $\left[\mathrm{Cr}(\mathbf{9}) \mathrm{Cl}_{3}\right]$}

Complex $\left[\mathrm{Cr}(\mathbf{9}) \mathrm{Cl}_{3}\right]$ was synthesised by an analogous procedure to that described for $\left[\mathrm{Cr}(\mathbf{1}) \mathrm{Cl}_{3}\right]$ using $N, N$-bis(1H-benzimidazol-2-ylmethyl)- $N$-phenylamine 9 (0.20 g, 0.56 $\mathrm{mmol})$ and $\left[\mathrm{CrCl}_{3}(\mathrm{THF})_{3}\right](0.21 \mathrm{~g}, 0.56 \mathrm{mmol})$. Yield $0.23 \mathrm{~g}$ (87\%). Anal. Calc. for $\mathrm{C}_{22} \mathrm{H}_{19} \mathrm{Cl}_{3} \mathrm{CrN}_{5}$ (F.W. 511.8): C 51.63, H 3.74, N 13.68 \%. Found C 51.49, H 3.95, N 13.58 \%. IR (KBr, $\left.\mathrm{cm}^{-1}\right), 3503$ (NH, s), 3224, 3065, 1622-1545 (ArC=C, C=N, m), 1497, 1478, $1454(\mathrm{NH}, \mathrm{s}), 1275$ (CN, s), 748 (CH, s). UV-VIS (DMF), $\lambda_{\max } / \mathrm{nm}=484,678$, 705(shoulder). $\mathrm{FAB}(+) \mathrm{MS}(\mathrm{m} / \mathrm{z}): 475[\mathrm{M}-\mathrm{Cl}]^{+}, 440[\mathrm{M}-2 \mathrm{Cl}]^{+}, 354\left[\mathrm{M}-\mathrm{CrCl}_{3}\right]^{+} \cdot \mu_{\mathrm{eff}}=3.95$ BM.

$N, N$-bis((1H-benzimidazol-2-yl)methyl)- $N$-(benzyl)amine chromium(III) chloride $\left[\mathrm{Cr}(\mathbf{1 0}) \mathrm{Cl}_{3}\right]$

Complex $\left[\mathrm{Cr}(\mathbf{1 0}) \mathrm{Cl}_{3}\right]$ was synthesised by an analogous procedure to that described for [Cr(1) $\left.\mathrm{Cl}_{3}\right]$ using 10 (0.63 g, $\left.1.73 \mathrm{mmol}\right)$ and $\left[\mathrm{CrCl}_{3}(\mathrm{THF})_{3}\right](0.65 \mathrm{~g}, 1.73 \mathrm{mmol})$. Yield $0.79 \mathrm{~g}$ (88\%). Anal. Calc. for $\mathrm{C}_{23} \mathrm{H}_{21} \mathrm{Cl}_{3} \mathrm{CrN}_{5}$ (F.W. 525.8): C 52.54, H 4.03, N 13.32 \%. Found C 52.43, H 4.03, N 13.23 \%. IR (KBr, $\mathrm{cm}^{-1}$ ), 3255 (NH, s), 1617-1550 (ArC=C, C=N, m), 1496, 1477, 1454 (NH, s, m), 1276 (CN, s), 749 (CH, s). UV-VIS (DMF, $298 \mathrm{~K}, \lambda_{\max } / \mathrm{nm}$ $\left.\left(\varepsilon_{\max } / \mathrm{dm}^{3} \mathrm{~mol}^{-1} \mathrm{~cm}^{-1}\right)\right)=462$ (162), 665 (75), 726 (shoulder). FAB $(+)$ MS: $(\mathrm{m} / \mathrm{z}), 489$ [M$\mathrm{Cl}]^{+}, 454[\mathrm{M}-2 \mathrm{Cl}]^{+} . \mu_{\mu \mathrm{eff}}=4.00 \mathrm{BM}$.

\section{$N, N$-bis((1H-benzimidazol-2-yl)methyl)- $N$-(2,6-dimethylphenyl)amine chromium(III) chloride $\left[\mathrm{Cr}(\mathbf{1 1}) \mathrm{Cl}_{3}\right]$}

Complex $\left[\mathrm{Cr}(\mathbf{1 1}) \mathrm{Cl}_{3}\right]$ was synthesised by an analogous procedure to that described for [Cr(1) $\left.\mathrm{Cl}_{3}\right]$ using $N, N$-bis(1H-benzimidazol-2-ylmethyl)- $N$-(2,6-dimethylphenyl)amine 11 $(0.20 \mathrm{~g}, 0.53 \mathrm{mmol})$ and $\left[\mathrm{CrCl}_{3}(\mathrm{THF})_{3}\right](0.19 \mathrm{~g}, 0.53 \mathrm{mmol})$. Yield $0.23 \mathrm{~g}(81 \%)$. Anal. Calc. for $\mathrm{C}_{24} \mathrm{H}_{23} \mathrm{Cl}_{3} \mathrm{CrN}_{5}$ (F.W. 555.9): C 53.40, H 4.29, N 12.97 \%. Found C 53.51, H 4.39, N 
12.82 \%. IR (KBr, cm $\left.{ }^{-1}\right), 3252$ (NH, m), 3189 (Ar-H), 1622, 1591, 1520 (ArC=C, C=N, m), 1466, $1451(\mathrm{NH}, \mathrm{s}), 1273$ (CN, s), 742 (CH, s). UV-VIS (DMF), $\lambda_{\max } / \mathrm{nm}\left(\varepsilon_{\max } / \mathrm{dm}^{3} \mathrm{~mol}^{-1}\right.$ $\left.\mathrm{cm}^{-1}\right)=482(70), 678(58), 705$ (shoulder). $\mathrm{FAB}(+) \mathrm{MS}(\mathrm{m} / \mathrm{z}), 503[\mathrm{M}-\mathrm{Cl}]^{+}, 468[\mathrm{M}-2 \mathrm{Cl}]^{+}$, $382\left[\mathrm{M}-\mathrm{CrCl}_{3}\right] \cdot \mu_{\mathrm{eff}}=3.89 \mathrm{BM}$.

\section{$N, N$-bis((1-Me-benzimidazol-2-yl)methyl)amine chromium(III) chloride $\left[\mathrm{Cr}(12) \mathrm{Cl}_{3}\right]$}

A slurry of $0.50 \mathrm{~g}$ (1.64 mmol) N,N-bis(2-(1Me-benzimidazol-2-yl)methyl)amine 12 and 0.61 $\mathrm{g}(1.64 \mathrm{mmol})\left[\mathrm{CrCl}_{3}(\mathrm{THF})_{3}\right]$ in $20 \mathrm{ml}$ THF was stirred at reflux for 4 hours. The obtained green solid was filtered, washed with THF $(3 \times 10 \mathrm{~mL})$ and dried under reduced pressure. Yield 0.39 g (51.0\%). Anal. Calc. for $\mathrm{C}_{18} \mathrm{H}_{19} \mathrm{~N}_{5} \mathrm{CrCl}_{3}$, C 46.62, H 4.13, N 15.10. Found C 46.54, H 4.15, N 15.01. FT-IR, cm ${ }^{-1}$ : 3246(s), 2857 (m), 1621 (m), 1541 (w), 1492 (m), 1474 (v.s), 1465 (v.s), 1414 (m), 1382 (m), 1331 (m), 1272 (s), 1210 (w), 1147 (w), 1055 (s), 1003 (s), 981 (s), 944 (w), 919 (m), 977 (s), 752 (v.s), 702 (s), 654 (m), 558 (w), 518 (w), 510 (w), $431(\mathrm{w}), 418(\mathrm{w}) \cdot \square \mu_{\text {eff }}=3.91 \mathrm{BM}$.

$N, N$-bis((1-Me-benzimidazol-2-yl)methyl)- $N$-(methyl)amine chromium(III) chloride $\left[\mathrm{Cr}(\mathbf{1 3}) \mathrm{Cl}_{3}\right]$

A slurry of $0.50 \mathrm{~g} \quad(1.56 \mathrm{mmol}) \quad N, N$-bis(2-(1-Me-benzimidazol-2-yl)methyl)- $N$ (methyl)amine 13 and $0.59 \mathrm{~g}(1.56 \mathrm{mmol})\left[\mathrm{CrCl}_{3}(\mathrm{THF})_{3}\right]$ in $20 \mathrm{ml}$ THF was stirred at reflux for 4 hours. The obtained green solid was filtered, washed with THF (3x10 mL) and dried under reduced pressure. Yield $0.64 \mathrm{~g}$ (85.8\%). Anal. Calc. for $\mathrm{C}_{19} \mathrm{H}_{21} \mathrm{~N}_{5} \mathrm{CrCl}_{3}$, $\mathrm{C}$ 47.77, $\mathrm{H}$ 4.43, N 14.66. Found, C 47.59, H 4.40, N 14.64. FT-IR, $\mathrm{cm}^{-1}$ : 3246 (v.s), 2857 (s), 1621 (m), 1595 (m), 1541 (w), 1492 (m), 1475 (v.s), 1462 (v.s), 1382 (m), 1382 (s), 1332 (m), 1272 (s), 1210 (w), 1146 (w), 1094 (w), 1055 (m), 1003 (s), 982 (s), 944 (w), 919 (m), 878 (s), 752 (v.s), 702 (s), $654(\mathrm{~m}), 558(\mathrm{w}), 518(\mathrm{w}), 510(\mathrm{w}), 431(\mathrm{w}), 417(\mathrm{w}) . \quad \mu_{\text {eff }}=3.74$ BM.

\section{O-bis((1H-benzimidazol-2-ylmethyl)-ether chromium (III) chloride $\left[\mathrm{Cr}(14) \mathrm{Cl}_{3}\right]$}

Complex $\left[\mathrm{Cr}(\mathbf{1 4}) \mathrm{Cl}_{3}\right]$ was synthesised by a procedure analogous to that described for [Cr(1) $\left.\mathrm{Cl}_{3}\right]$ using $14(0.7 \mathrm{~g}, 2.5 \mathrm{mmol})$ and $\left[\mathrm{CrCl}_{3}(\mathrm{THF})_{3}\right](0.94 \mathrm{~g}, 2.5 \mathrm{mmol})$ in $20 \mathrm{ml}$ of THF. Yield 0.96 g, 85\%. Anal. Calc. for $\mathrm{C}_{16} \mathrm{H}_{14} \mathrm{Cl}_{3} \mathrm{CrN}_{4} \mathrm{O}$ (F.W. 436.7): C 44.01, H 3.23, N 12.83 \%. Found C 44.19, H 3.38, N 12.70 \%. IR (KBr, cm $\left.{ }^{-1}\right), 3232(\mathrm{NH}, \mathrm{s}), 1620-1540$ $(\mathrm{ArC}=\mathrm{C}, \mathrm{C}=\mathrm{N}, \mathrm{m}), 1477-1454(\mathrm{~N}-\mathrm{H}, \mathrm{s}), 1054-1043(\mathrm{C}-\mathrm{O}, \mathrm{s}), 749(\mathrm{CH}, \mathrm{s}) . \mathrm{FAB}(+) \mathrm{MS}(\mathrm{m} / \mathrm{z})$, $400[\mathrm{M}-\mathrm{Cl}]^{+}, 365[\mathrm{M}-2 \mathrm{Cl}]^{+}, 329[\mathrm{M}-3 \mathrm{Cl}]^{+} . \mu_{\mathrm{eff}}=3.66 \mathrm{BM}$. 


\section{S-bis((1H-benzimidazol-2-yl)methyl)-thioether chromium(III) chloride $\left[\mathrm{Cr}(15) \mathrm{Cl}_{3}\right]$}

Complex $\left[\mathrm{Cr}(\mathbf{1 5}) \mathrm{Cl}_{3}\right]$ was synthesised by a procedure analogous to that described for [Cr(1)Cl $\left.\mathrm{Cl}_{3}\right]$ using 15 (0.58 g, $\left.1.96 \mathrm{mmol}\right)$ and $\left[\mathrm{CrCl}_{3}(\mathrm{THF})_{3}\right](0.73 \mathrm{~g}, 1.96 \mathrm{mmol})$. Yield 0.75 g, 85\%. Anal. Calc. for $\mathrm{C}_{16} \mathrm{H}_{14} \mathrm{Cl}_{3} \mathrm{CrN}_{4} \mathrm{~S}$ (F.W. 452.7): C 42.45, H 3.12, N 12.38 \%. Found C 42.59, H 3.22, N 12.27 \%. IR (KBr, cm $\left.{ }^{-1}\right), 3448$ (Ar-H, s), 1622, $1593(\mathrm{C}=\mathrm{C}, \mathrm{C}=\mathrm{N}, \mathrm{m})$, 1486, 1467, 1452 (N-H, s), 1277 (C-N, s), 1046 (CS, s), 744(CH, s). FAB(+) MS (m/z), 416 $[\mathrm{M}-\mathrm{Cl}]^{+}, 381[\mathrm{M}-2 \mathrm{Cl}]^{+} . \mu_{\mathrm{eff}}=3.89 \mathrm{BM}$.

\section{1,1-Bis(1H-benzimidazol-2-ylmethyl)-ethane chromium(III) chloride [ $\left.\mathrm{Cr}(16) \mathrm{Cl}_{3}\right]$}

Complex $\left[\mathrm{Cr}(\mathbf{1 6}) \mathrm{Cl}_{3}\right]$ was synthesised by a procedure analogous to that described for [Cr(1) $\left.\mathrm{Cl}_{3}\right]$ using $16(0.6 \mathrm{~g}, 2.07 \mathrm{mmol})$ and $\left[\mathrm{CrCl}_{3}(\mathrm{THF})_{3}\right](0.78 \mathrm{~g}, 2.07 \mathrm{mmol})$. Yield $0.86 \mathrm{~g}$, 92 \%. Anal. Calc. for $\mathrm{C}_{18} \mathrm{H}_{18} \mathrm{Cl}_{3} \mathrm{CrN}_{4}$ (F.W. 448.7): C 48.18, H 4.04, N 12.49 \%. Found C 48.10, H 4.17, N 12.31 \%. IR (KBr, cm ${ }^{-1}$ ), v 3384 (Ar-H, s), v 1626-1560 (ArC=C, C=N, s), $\delta 1488,1460(\mathrm{~N}-\mathrm{H}, \mathrm{s}), v 1222(\mathrm{NC}, \mathrm{s}), \delta 757(\mathrm{CH}, \mathrm{s}) . \mathrm{FAB}(+) \mathrm{MS}(\mathrm{m} / \mathrm{z}), 412[\mathrm{M}-\mathrm{Cl}]^{+}, 377$ $[\mathrm{M}-2 \mathrm{Cl}]^{+} . \mu_{\mathrm{eff}}=3.88 \mathrm{BM}$.

\section{$N$-bis((1H-benzimidazol-2-yl)ethyl)amine chromium chloride $\left[\mathrm{Cr}(18) \mathrm{Cl}_{3}\right]$}

Ligand 18 (0.20 g, 0.49 mmols), chromium(III) chloride tetrahydrofuran complex (0.246 g, 0.49 mmols) and $20 \mathrm{~mL}$ of dry THF were stirred and heated at $60{ }^{\circ} \mathrm{C}$ for 16 hours under a nitrogen atmosphere. An insoluble solid formed which was filtered off, washed with $10 \mathrm{~mL}$ of dry THF and dried in vacuo. The product was obtained as a light brown amorphous solid; 0.151 g (66 \%); IR $v_{\max } / \mathrm{cm}^{-1}(\mathrm{KBr}) 3445$ (m, N-H stretch), 3168, 2808 (s, aromatic and aliphatic C-H stretch), 1619, 1540 (m, C=N stretch), 1456, 1403 (s, aromatic C=C stretch and aliphatic C-H bending), 1260 (s, C-N stretch), 759 (s, aromatic C-H bending); MS (LSIMS): $\mathrm{m} / \mathrm{z} 427\left([\mathrm{M}-\mathrm{Cl}]^{+}, 15 \%\right)$ \& $392\left([\mathrm{M}-2 \mathrm{Cl}]^{+}, 10 \%\right)$; Calc. for $\mathrm{C}_{18} \mathrm{H}_{19} \mathrm{~N}_{5} \mathrm{CrCl}_{3}: \mathrm{C}, 46.60 ; \mathrm{H}$, 4.13; N, 15.11. Found: C, 46.69; H, 3.91; N, $14.91 \%$; $\mu_{\mathrm{eff}}=3.5$ BM.

\section{$N$-bis((1H-benzimidazol-2-yl)ethyl)- $N$-(methyl)amine chromium chloride $\left[\mathrm{Cr}(19) \mathrm{Cl}_{3}\right]$}

Compound 19 (0.20 g, 0.60 mmols), chromium(III) chloride tetrahydrofuran complex (0.225 g, 0.60 mmols) and $20 \mathrm{~mL}$ of dry DCM were stirred and heated at $35{ }^{\circ} \mathrm{C}$ for 16 hours under a nitrogen atmosphere. An insoluble solid formed which was filtered off, washed with $10 \mathrm{~mL}$ of dry THF and $10 \mathrm{~mL}$ of dry DCM and dried in vacuo. The product was obtained as a lilac amorphous solid; 0.145 g (49 \%); IR $v_{\max } / \mathrm{cm}^{-1}$ (KBr) 3408 (m, N-H stretch), 3151, 2968 (s, 
aromatic and aliphatic C-H stretch), 1618, 1560 (m, C=N stretch), 1485, 1458 (s, aromatic $\mathrm{C}=\mathrm{C}$ stretch and aliphatic C-H bending), 1274 (s, C-N stretch), 746 (s, aromatic C-H bending); MS (LSIMS): m/z 455 ([M-Cl $\left.]^{+}, 10 \%\right) \& 420$ ([M-2Cl $\left.]^{+}, 5 \%\right)$; Calc. for $\mathrm{C}_{20} \mathrm{H}_{23} \mathrm{~N}_{5} \mathrm{CrCl}_{3}$ : C, 48.83; H, 4.72; N, 14.24. Found: C, 48.69; H, 4.61; N, $14.03 \% ; \mu_{\text {eff }}=4.2$ BM.

\section{Bis(1H-benzimidazol-2-yl)methane chromium(III) trichloride $\left[\mathrm{Cr}(20) \mathrm{Cl}_{3}\right]$}

The ligand $20(0.626 \mathrm{~g}, 2.5 \mathrm{mmol})$ and $\left[\mathrm{CrCl}_{3}(\mathrm{THF})_{3}\right](0.943 \mathrm{~g}, 2.5 \mathrm{mmol})$ were combined in $30 \mathrm{ml}$ THF under nitrogen. The mixture was stirred for 3 days and the intensely dark green suspension was filtered, washed with thf and dried, to leave the product as a dark green powder (0.730 g, 78\%). IR $v_{\max } / \mathrm{cm}^{-1}(\mathrm{KBr}) 3126$ (br, N-H stretch), 1624 (m, C=N stretch), 1595 and 1537 (m, aromatic C=C stretch and aliphatic C-H bending), 1467 (s, NH, bend), 1047 (m), 744 (s, aromatic C-H bending) 333 (s, N-Cr). MS (ESI): m/z 404 $\left([\mathrm{M}+\mathrm{H}+\mathrm{MeOH}]^{+}, 15 \%\right)$. Calc. for $\mathrm{C}_{15} \mathrm{H}_{12} \mathrm{~N}_{4} \mathrm{CrCl}_{3}$ : C, 44.30; H, 2.97; N, 13.78. Found: C, 44.42; H, 3.16; N, $13.59 \%$.

$N$-Bis((3,5-dimethylpyrazol-1-yl)methyl)- $N$-(butyl)amine chromium(III) chloride $\left[\mathrm{Cr}(\mathbf{2 1}) \mathrm{Cl}_{3}\right]$

A solution of $0.50 \mathrm{~g}$ (1.73 mmol) $N$-bis((3,5-dimethylpyrazol-1-yl)methyl)- $N$-(butyl)amine (21) in $10 \mathrm{ml}$ dry THF was added to a suspension of $0.65 \mathrm{~g}(1.73 \mathrm{mmol})\left[\mathrm{CrCl}_{3}(\mathrm{THF})_{3}\right]$ in 10 $\mathrm{ml}$ THF and the reaction mixture stirred at room temperature for 18 hours. Shortly after the start the colour of the reaction mixture changed from purple to green and at the end of the reaction green precipitate was formed. The solid was filtered off, washed with $5 \mathrm{ml}$ tetrahydrofuran and $3 \times 10 \mathrm{ml}$ diethyl ether and dried at room temperature under reduced pressure for 5 hours. Yield - 0.72g (93.4\%). Anal. Calc. for (found): C 42.92 (42.83), H 6.08 (6.17), N 15.64 (15.54). FT-IR ( $\mathrm{cm}^{-1}$ ): 574 (v.w), 600 (v.w), 628 (w), 695 (w), 796 (s), 845 (m), 966 (w), 1031 (s), 1053 (v.s), 1119 (s), 1139 (w), 1258 (m), 1279 (s), 1300 (s), 1377 (v.s), 1418 (v.s), 1422 (s), 1465 (v.s), 1492 (s), 1557 (v.s), 2873 (m), 2932 (s), 2961 (v.s), $3127(\mathrm{w}) \cdot \mu_{\mathrm{eff}}=3.98 \mathrm{BM}$ 
Freshly prepared $\left[\mathrm{Cr}(\mathrm{CO})_{3}(\mathrm{NCMe})_{3}\right](0.08 \mathrm{~g}, 0.32 \mathrm{mmol})$, from $\left[\mathrm{Cr}(\mathrm{CO})_{6}\right](2.00 \mathrm{~g}, 9.10$ mmol) heated at reflux for $24 \mathrm{~h}$ in acetonitrile $(60 \mathrm{~mL})$, and $2(0.09 \mathrm{~g}, 0.32 \mathrm{mmol})$ were stirred overnight in THF at room temperature. The product was isolated by filtration, washed with $\mathrm{Et}_{2} \mathrm{O}(3 \times 10 \mathrm{~mL})$ and dried under vacuum. $\left[\mathrm{Cr}(2)(\mathrm{CO})_{3}\right]$ was obtained as an orange airsensitive solid. Recrystallisation from cold $\left(-20^{\circ} \mathrm{C}\right)$ THF solution gave crystals suitable for $\mathrm{X}$-ray analysis. Yield 0.12 g, 85\%. Anal. Calc. for $\mathrm{C}_{20} \mathrm{H}_{17} \mathrm{CrN}_{5} \mathrm{O}_{3}$ (F.W. 427.4): C 56.21, H 4.01, N 16.39 \%. Found C 56.17, H 4.15, N 16.42 \%. ${ }^{1} \mathrm{H}$ NMR (250 MHz, J = Hz, DMSO$\left.\mathrm{d}_{6}\right), \delta 3.26\left(\mathrm{~s}, 3 \mathrm{H}, \mathrm{NCH}_{3}\right), 4.19\left(\mathrm{dd},{ }^{2} J_{\mathrm{HaHb}}=16.90, \mathrm{CH}_{\mathrm{a}} H_{\mathrm{b}}\right), 7.16\left(\mathrm{~m}, 4 \mathrm{H},{ }^{\mathrm{n}} J_{\mathrm{HH}}=7.33, \operatorname{Ar} H\right)$, $7.34\left(\mathrm{~d}, 2 \mathrm{H}, J_{\mathrm{HH}}=7.33, \operatorname{ArH}\right), 8.02\left(\mathrm{~d}, 2 \mathrm{H}, J_{\mathrm{HH}}=7.93, \operatorname{ArH}\right) .{ }^{13} \mathrm{C}\left\{{ }^{1} \mathrm{H}\right\}$ NMR $(62.9 \mathrm{MHz}$, DMSO-d $\left.\mathrm{d}_{6}\right) \delta 25.1\left(\mathrm{NCH}_{3}\right), 60.1\left(\mathrm{NCH}_{2} \mathrm{C}_{\mathrm{q}}\right), 111.7(\operatorname{ArC}), 118(\operatorname{ArC}), 122.6(\operatorname{ArC}), 134.0$ $(\operatorname{ArC}), 141.8\left(\operatorname{Ar}_{\text {ipso }}\right), 153.9\left(\operatorname{Ar} C_{\mathrm{q}}\right), 223.1(C=\mathrm{O}) . \quad F A B(+) \mathrm{MS}(\mathrm{m} / \mathrm{z}), 427[\mathrm{M}]^{+}, 358[\mathrm{M}-$ 2(CO)-Me $]^{+}, 343[\mathrm{M}-3(\mathrm{CO})]^{+}$.

\section{Cationic complexes}

\section{Trans-dichloro(mer- $N$-bis((1H-benzimidazol-2-yl)methyl)amine)(tetrahydrofuran) chromium(III) hexafluoroantimonate $\left[\mathrm{Cr}(\mathbf{1}) \mathrm{Cl}_{2}(\mathrm{thf})\right] \mathrm{SbF}_{6}$}

Silver hexafluoroantimonate $(0.24 \mathrm{~g}, 0.69 \mathrm{mmol})$ and complex $\left[\operatorname{Cr}(\mathbf{1}) \mathrm{Cl}_{3}\right](0.3 \mathrm{~g}, 0.69 \mathrm{mmol})$ were stirred in THF $(20 \mathrm{ml})$ at room temperature overnight. The solution was filtered, the solvent removed under reduced pressure, the product washed twice with diethyl ether $(2 \times 20$ $\mathrm{ml}$ ) and dried under vacuum. Attempts to crystallise the complex from a THF solution resulted in blue crystals that were analysed as $\left[\mathrm{Cr}(\mathbf{1}) \mathrm{Cl}_{2}\left(\mathrm{OH}_{2}\right)\right] \mathrm{SbF}_{6}$, probably due to adventitious moisture in the system. Yield $0.375 \mathrm{~g}$ (77 \%). Anal. Calc. for $\mathrm{C}_{20} \mathrm{H}_{23} \mathrm{Cl}_{2} \mathrm{CrF}_{6} \mathrm{~N}_{5} \mathrm{OSb}$ (F.W. 708.1): C 33.92, H 3.27, N 9.80 \%. Found C 33.70, H 3.26, N 9.60 \%. IR (KBr, cm ${ }^{-1}$ ), 3202 (NH, m), 3164 (Ar-H), 1622-1544 (ArC=C, C=N, m), 1497, 1477, 1456 (N-H, s), 1278 (CN, s), 748 (CH, s), 660 (Sb-F, s). UV-VIS (DMF), $\lambda_{\max } / \mathrm{nm}$ $\left(\varepsilon_{\max } / \mathrm{dm}^{3} \mathrm{~mol}^{-1} \mathrm{~cm}^{-1}\right)=440$ (120), 647 (100), 726 (shoulder). FAB(+) MS (m/z), 401 [M$\mathrm{THF}]^{+}, 364[\mathrm{M}-\mathrm{THF}-\mathrm{Cl}]^{+}, 328[\mathrm{M}-\mathrm{THF}-2 \mathrm{Cl}]^{+} . \mathrm{FAB}(-) \mathrm{MS}(\mathrm{m} / \mathrm{z}), 235\left[\mathrm{SbF}_{6}\right]^{-} \cdot \mu_{\mathrm{eff}}=4.10$ BM.

Cis-dichloro(fac- $\mathrm{N}$-bis(1H-benzimidazol-2-ylmethyl)- $\mathrm{N}$ (phenyl)amine)(tetrahydrofuran) chromium(III) $\left[\mathrm{Cr}(\mathbf{9}) \mathrm{Cl}_{2}(\mathrm{thf})\right] \mathrm{SbF}_{6}$ 
The procedure used was as described for $\left[\mathrm{Cr}(\mathbf{1}) \mathrm{Cl}_{2}(\mathrm{thf})\right] \mathrm{SbF}_{6}$, using ligand 9 (0.09 g, 0.18 mmol) and silver hexafluoroantimonate $(0.06 \mathrm{~g}, 0.18 \mathrm{mmol})$ to afford $\left[\mathrm{Cr}(\mathbf{9}) \mathrm{Cl}_{2}(\right.$ thf $\left.)\right] \mathrm{SbF}_{6}$ as a green solid. Yield 0.10 g (72 \%). Anal. Calc. for $\mathrm{C}_{26} \mathrm{H}_{27} \mathrm{Cl}_{2} \mathrm{Cr}_{6} \mathrm{~N}_{5} \mathrm{OSb}$ (F.W. 784.2): C 39.82, H 3.47, N 8.93 \%. Found C 39.72, N 3.58, N 8.73 \%. IR (KBr, cm $\left.{ }^{-1}\right), 3390$ (NH, s), 3066 (Ar-H, s), 1623-1554 (ArC=C, N=C, m), 1498, 1479, 1454 (N-H, s), 1276 (CN, m), 1053 (C-O, m), 751 (CH, s), 665 (Sb-F, vs). UV-VIS (DMF), $\lambda_{\max } / \mathrm{nm}\left(\varepsilon_{\max } / \mathrm{dm}^{3} \mathrm{~mol}^{-1} \mathrm{~cm}^{-1}\right)$, 441(118), 644(103), 725. FAB(+) MS (m/z), 475 [M-(SbF $\left.)_{6}-\mathrm{THF}\right]^{+}, 440\left[\mathrm{M}-\left(\mathrm{SbF}_{6}\right)-\mathrm{THF}-\right.$ $\mathrm{Cl}]^{+}$. FAB(-) MS (m/z), $235\left[\mathrm{SbF}_{6}\right]^{-} \cdot \mu_{\mathrm{eff}}=4.12 \mathrm{BM}$.

\section{Bis(benzimidazol-2-ylmethyl)methylamine(dimethyl)aluminium trimer $\left[\left(\mathrm{AlMe}_{2}\right)_{2}\left(2^{\prime}\right)\right]_{3}$}

A solution of trimethylaluminium in heptane (2M, $1.7 \mathrm{ml}, 3.4 \mathrm{mmol})$ was added to a suspension of $0.5 \mathrm{~g}$ (1.7 mmol) bis(benzimidazol-2-ylmethyl)methylamine (2) in $20 \mathrm{ml}$ dry toluene, at $-78{ }^{\circ} \mathrm{C}$. The reaction mixture was stirred at $-78{ }^{\circ} \mathrm{C}$ for 10 minutes and the cooling bath removed. While warming up to room temperature, the solid gradually dissolved forming a pale blue solution. The reaction mixture was stirred additionally for 2 hours at room temperature and then approximately $3 / 4$ of the solvent removed under reduced pressure. The addition of $5 \mathrm{ml}$ dry n-heptane resulted in the formation of off-white precipitate, which was filtered, washed with $5 \mathrm{ml}$ cold n-heptane and dried under reduced pressure. Crystals suitable for X-ray analysis were obtained from a toluene/heptane solution. Yield - $0.55 \mathrm{~g}(80 \%) .{ }^{1} \mathrm{H}$ NMR (400 MHz, $\left.\mathrm{C}_{6} \mathrm{D}_{6}, 298 \mathrm{~K}\right), \mathrm{ppm}: 7.08$ - 7.55 (28H, Ar-H), 2.18 - 3.92 (21H, $\mathrm{CH}_{2}-\mathrm{N}$ and $\left.\mathrm{CH}_{3}-\mathrm{N}\right),-0.88$ - 1.58 (36H, CH $\left.3-\mathrm{Al}\right) .{ }^{13} \mathrm{C}\left\{{ }^{1} \mathrm{H}\right\}$ NMR (101 MHz, $\left.\mathrm{C}_{6} \mathrm{D}_{6}, 298 \mathrm{~K}\right), \mathrm{ppm}: 153.9$, 153.7, 153.5, 142.4, 142.0, 141.9, 139.4, 138.9, 138.8, 137.7, 129.3, 128.5, 125.6, 123.9, 123.6, 123.4, 122.8, 122.2, 117.3, 117.1, 116.9, 116.2, 115.8, 115.4, 58.2, 57.2, 44.9, 43.8, $21.7,-5.1,-5.7,-6.1,-6.5$.

General Polymerisation Procedure. Due to the insoluble nature of the chromium catalysts in the polymerisation solvent, toluene, the complexes were first pre-activated with the co-catalyst, methylaluminoxane (MAO). This solution was diluted with toluene in order to give a solution with a suitable catalyst concentration. The activated catalyst solution showed no significant loss of activity when stored at $5{ }^{\circ} \mathrm{C}$ for up to 2 weeks. In practice, catalyst solutions were freshly prepared by combining the pre-catalyst with the co-catalyst at room temperature and the activated solutions were used within the same day. A mechanically stirred pressure reaction vessel was filled with toluene $(200 \mathrm{~mL})$ followed by 
addition of MAO as a moisture scavenger. The pressure reaction vessel was submerged in a water bath set to the desired polymerisation temperature and the solvent saturated with ethylene at a pressure of 1 bar. The polymerisation was initiated by injection of an aliquot of the activated catalyst solution. Immediately after the injection the ethylene pressure was adjusted to the required pressure and kept constant over the reaction time. Reaction temperatures were measured inside the reactor. For highly active catalysts, nano-molar concentrations of catalyst were used in order to limit the rise in reaction temperature to less than $3{ }^{\circ} \mathrm{C}$. After one hour the reaction was terminated by turning off the ethylene supply and venting off excess unreacted monomer. A known amount of GC standard (nonane or 2,2,4,4,6,8,8-heptamethylnonane) was added to the reaction mixture and then a small sample of the liquid phase was taken and passed through neutral alumina $\left(\mathrm{Al}_{2} \mathrm{O}_{3}\right.$ micro column) to remove any catalyst, and then analysed by FID-GC. The remaining polymer product was precipitated by the addition of methanol (200 mL), followed by dilute $\mathrm{HCl}(20 \mathrm{~mL})$.

\section{Supporting Information}

NMR spectra, GC chromatograms, additional graphs, crystallographic details and information regarding DFT calculations.

\section{Acknowledgements}

Financial support from INEOS Technologies is kindly acknowledged. We thank the Australian Research Council for financial support through grant FT100100609 to D.S.M. We thank the STFC for beam time at Daresbury Laboratory and Drs. Jonathan E. Warren and Timothy J. Prior for scientific support.

\section{References}

(1) Breuil, P.-A. R.; Magna, L.; Olivier-Bourbigou, H. Catal. Lett. 2015, 145, 173.

(2) Forestière, A.; Olivier-Bourbigou, H.; Saussine, L. Oil Gas Sci. Technol. 2009, 64, 649.

(3) Olivier-Bourbigou, H.; Forestière, A.; Saussine, L.; Magna, L.; Favre, F.; Hugues, F. Oil Gas Eur. Mag. 2010, 36, 97.

(4) Belov, G. P.; Matkovsky, P. E. Pet. Chem. 2010, 50, 283.

(5) Keim, W. Angew. Chem. Int. Ed. 2013, 52, 12492.

(6) Cossee, P. J. Catal. 1964, 3, 80.

(7) Schulz, G. V. Z. Physik. Chem. 1935, B30, 379. 
(8) Flory, P. J. J. Am. Chem. Soc. 1936, 58, 1877.

(9) McGuinness, D. S. Chem. Rev. 2011, 111, 2321.

(10) Agapie, T. Coord. Chem. Rev. 2011, 255, 861.

(11) van Leeuwen, P. W. N. M.; Clément, N. D.; Tschan, M. J.-L. Coord. Chem. Rev. 2011, 1499-1517.

(12) Dixon, J. T.; Green, M. J.; Hess, F. M.; Morgan, D. H. J. Organomet. Chem. 2004, 689, 3641.

(13) Sydora, O. L.; Jones, T. C.; Small, B. L.; Nett, A. J.; Fischer, A. A.; Carney, M. J. ACS Catal. 2012, 2, 2452.

(14) Radcliffe, J. E.; Batsanov, A. S.; Smith, D. M.; Scott, J. A.; Dyer, P. W.; Hanton, M. J. ACS Catal. 2015, 5, 7095.

(15) Reagen, W. K.; Conroy, B. K. (Phillips Petroleum Co.), CA 2020509, 1991.

(16) Blann, K.; Bollmann, A.; Dixon, J. T.; Neveling, A.; Morgan, D. H.; Maumela, H.; Killian, E.; Hess, F. M.; Otto, S.; Pepler, L.; Mohamed, H.; Overett, M. J. (Sasol Technology), WO 2004/056479 A1, 2004.

(17) Briggs, J. R. J. Chem. Soc. Chem. Commun. 1989, 674.

(18) Tomov, A.; Gibson, V. C.; Britovsek, G. J. P.; Long, R. J.; van Meurs, M.; Jones, D. J.; Tellmann, K. P.; Chirinos, J. J. Organometallics 2009, 28, 7033.

(19) Agapie, T.; Labinger, J. A.; Bercaw, J. E. J. Am. Chem. Soc. 2007, 129, 14281.

(20) Tomov, A. K.; Chirinos, J. J.; Long, R. J.; Gibson, V. C.; Elsegood, M. R. J. J. Am. Chem. Soc. 2006, 128, 7704.

(21) Tenza, K.; Hanton, M. J.; Slawin, A. M. Z. Organometallics 2009, 28, 4852.

(22) Britovsek, G. J. P.; McGuinness, D. S.; Wierenga, T. S.; Young, C. T. ACS Catal. 2015, 5, 4152.

(23) Cariou, R.; Chirinos, J. J.; Gibson, V. C.; Jacobsen, G.; Tomov, A.; Britovsek, G. J. P.; White, A. J. P. Dalton Trans. 2010, 39, 9039.

(24) Gibson, V. C.; Tomov, A. (BP Chemicals), WO 2004/083263, 2004.

(25) Jacobsen, G. B.; Chirinos, J. J.; Gibson, V. C. (INEOS Europe Ltd.), WO 2007/015074, 2007.

(26) Berends, H. P.; Stephan, D. W. Inorg. Chim. Acta 1984, 93, 173.

(27) Zhang, W.; Sun, W.-H.; Zhang, S.; Hou, J.; Wedeking, K.; Schultz, S.; Fröhlich, R.; Song, H. Organometallics 2006, 25, 1961.

(28) Yao, H.-C.; Li, M.-M.; Yang, G.-S.; Li, Z.-J.; Zhu, Y. Inorg. Chim. Acta 2007, 360, 3959. 
(29) Touzani, R.; Ramdani, A.; Ben-Hadda, T.; El Kadiri, S.; Maury, O.; Le Bazec, H.; Dixneuf, P. H. Synth. Comm. 2001, 31, 1315.

(30) Sorrell, T. N.; Garrity, M. L. Inorg. Chem. 1991, 30, 210.

(31) Casella, L.; Monzani, E.; Gullotti, M.; Gliubich, F.; De Gioia, L. J. Chem. Soc., Dalton Trans. 1994, 3203.

(32) Ceniceros-Gómez, A. E.; Barba-Behrens, N.; Quiroz-Castro, M. E.; Bernès, S.; Nôth, H.; Castillo-Blum, S. E. Polyhedron 2000, 19, 1821.

(33) Rucklidge, A. J.; McGuinness, D. S.; Tooze, R. P.; Slawin, A. M. Z.; Pelletier, J. D. A.; Hanton, M. J.; Webb, P. B. Organometallics 2007, 26, 2782.

(34) Dulai, A.; de Bod, H.; Hanton, M. J.; Smith, D. M.; Downing, S.; Mansell, S. M.; Wass, D. F. Organometallics 2009, 28, 4613.

(35) Cariou, R.; Chirinos, J. J.; Gibson, V. C.; Jacobsen, G.; Tomov, A.; Elsegood, M. R. J. Macromolecules 2009, 42, 1443.

(36) Shiu, K.-B.; Chou, J. L.; Wang, Y.; Lee, G.-H. J. Chem. Soc., Dalton Trans. 1990, 1989.

(37) Wu, H.-L.; Kou, F.; Jia, F.; Liu, B.; Yuan, J.-K.; Bai, Y. J. Coord. Chem. 2011, 64, 3041.

(38) Tavman, A.; Sayil, C. J. Serb. Chem. Soc. 2015, 80, 45.

(39) Tomov, A.; Chirinos, J. J.; Jones, D. J.; Long, R. J.; Gibson, V. C. J. Am. Chem. Soc. 2005, 127, 10166.

(40) de Lazaro Casagrande Jr., O.; Klotz Rabello, C. R.; Losch de Oliveira, L.; Dias Pereira dos Santos, A. H.; Campedelli, R.; Lauro Bergamo, A. (Petrobras), US 2012/0178939, 2012.

(41) Junges, F.; Kuhn, M. C. A.; dos Santos, A. H. D. P.; Carpentier, J.-F.; Casagrande, O. L. Organometallics 2007, 26, 4010.

(42) Zhang, J.; Braunstein, P.; Hor, T. S. A. Organometallics 2008, 27, 4277.

(43) Britovsek, G. J. P.; Malinowski, R.; McGuinness, D. S.; Nobbs, J. D.; Tomov, A.; Wadsley, A. W.; Young, C. T. ACS Catal. 2015, 5, 6922.

(44) Kuhlmann, S.; Paetz, C.; Hägele, C.; Blann, K.; Walsh, R.; Dixon, J. T.; Scholz, J.; Haumann, M.; Wasserscheid, P. J. Catal. 2009, 262, 83.

(45) Walsh, R.; Morgan, D. H.; Bollmann, A.; Dixon, J. T. Appl. Catal. A: Gen. 2006, 306, 184.

(46) McGuinness, D. S. Organometallics 2009, 28, 244.

(47) Do, L. H.; Labinger, J. A.; Bercaw, J. E. Organometallics 2012, 31, 5143.

(48) Bowen, L. E.; Wass, D. F. Organometallics 2006, 25, 555. 
(49) McGuinness, D. S.; Suttil, J. A.; Gardiner, M. G.; Davies, N. W. Organometallics 2008, 27, 4238.

(50) Licciulli, S.; Thapa, I.; Albahily, K.; Korobkov, I.; Gambarotta, S.; Duchateau, R.; Chevalier, R.; Schuhen, K. Angew. Chem. Int. Ed. 2010, 49, 9225.

(51) Ronellenfitsch, M.; Wadepohl, H.; Enders, M. Organometallics 2014, 33, 5758.

(52) Rufino-Felipe, E.; Munoz-Hernández, M.-A. Chem. Commun. 2011, 47, 3210.

(53) Rufino-Felipe, E.; Munoz-Hernández, M.-A.; Saucedo-Azpeitia, H. F.; Cortes-Llames, S. A. Inorg. Chem. 2012, 51, 12834. 


\section{TOC Entry}

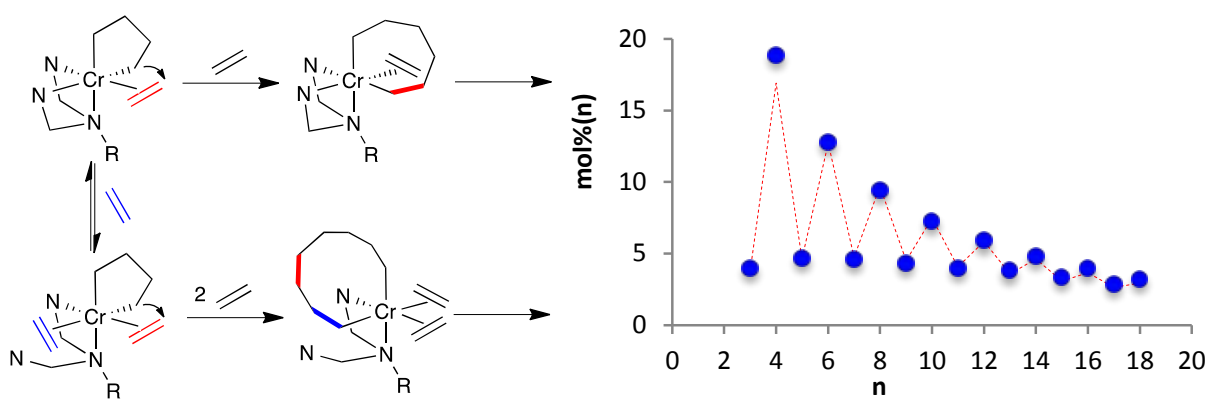

